\title{
The Molecular Genetics of Pediatric Lipid Disorders: Recent Progress and Future Research Directions ${ }^{1}$
}

\author{
STEVE E. HUMPHRIES, FRANCE MAILLY, VILMUNDUR GUDNASON, AND PHILIPPA TALMUD
}

Centre for Genetics of Cardiovascular Disorders. The Rayne Institute, London. United Kingdom

\begin{abstract}
Over the last 10 years, the explosion of molecular biology and molecular genetic techniques have allowed major advances in the diagnosis and management of a wide variety of human disorders. These range from accurate and simple screening for carriers of thalassemia (Old JM, Varawalla NY, Weatherall DJ: Lancet 2:834$837,1990)$ to the use of preimplantation diagnosis of embryos at risk for untreatable congenital defects (Monk $M$, Holding C: Lancet 1:985-988, 1990) and the development of gene therapy for treatment of disorders such as adenosine deaminase deficiency (Sharp D: Lancet 1:1277$1278,1991)$. These same molecular techniques have also been applied to pediatric lipid disorders with some notable successes, both in their diagnosis and understanding the mechanisms of the resulting pathology, including the recent experiments (Wilson JM, Grossman M, Wu CH, Chowdhury NR, Wu GY, Chowdhury JR: J Biol Chem 267:963$967,1992)$ that have led to proposals to treat homozygous familial hypercholesterolemia by gene therapy. The purpose of this review is to detail this molecular genetic progress for two of the disorders that result in disturbed triglyceride metabolism in infants, lipoprotein lipase deficiency and apo CII deficiency, and four disorders that lead to disturbed cholesterol levels in infancy, abetalipoproteinemia, hypobetalipoproteinemia, familial defective apo B, and familial hypercholesterolemia. We will also address the question of how knowledge of the mutation causing the defect in a particular patient could be clinically useful and highlight areas of research for the future. (Pediatr Res 34: 403-415, 1993)
\end{abstract}

\section{Abbreviations}

FH, familial hypercholesterolemia

LPL, lipoprotein lipase

FDB, familial defective apo B100

PCR, polymerase chain reaction

SSCP, single-strand conformational polymorphism

TG, triglyceride

RFLP, restriction fragment length polymorphism

ABL, abetalipoproteinemia

HBL, hypobetalipoproteinemia

LDL-R, LDL-receptor

Received December 7. 1992; accepted April 29, 1993

Correspondence: Professor S. Humphries. Centre for Genetics of Cardiovascular Disorders, University College London Medical School, Department of Medicine, The Rayne Institute, University Street. London WCIE 6JJ, United Kingdom.

Supported by the British Heart Foundation (Grant RG 16), Grant ROI HL 39107-3 from the National Institutes of Health, and a generous grant from the John Pinto Foundation.

'This paper was presented at a Festchrift in honor of Professor Dame June Lloyd, former editor of Pediatric Research, on the occasion of her retirement.

\section{MOLECULAR TECHNIQUES FOR IDENTIFICATION OF MUTATIONS}

The genes for most of the apolipoproteins, enzymes, and receptors that are involved in lipid metabolism have now been cloned, and their DNA sequence and arrangement of introns and exons determined and published (reviewed in 1 and 2). The control of expression of these genes is very complex and must be coordinated in response to a number of environmental challenges, rapidly in the postprandial state and more slowly in adaptation to hormonal changes, for example, at puberty or during pregnancy. Molecular details of these control processes are not yet fully understood, but excellent progress has already been made (3). Taken together, this information provides the framework for the identification of the mutations occurring in different patients with pediatric lipid disorders.

Several methods have been published that allow rapid comparison of the sequence of specific fragments of DNA from different individuals amplified in vitro by PCR (4). The first uses chemical cleavage of mismatched bases in the duplex formed between two heterologous DNA fragments after hybridization (5). This is a slow but robust technique that has been used successfully to look for mutations in the apo B gene (6). Because it is based on chemical methods, the technique is able to detect all mismatched bases irrespective of sequence (7), and individuals can be identified who are heterozygous for any sequence difference compared with the normal "probe" DNA, which is radiolabeled with ${ }^{32} \mathrm{P}$ deoxycytidine triphosphate. Fragments of DNA of about 500-600 bp give good results, but for longer fragments the yield of amplified DNA is reduced, and cleaved mismatches within 50-60 bp of the ends of the DNA fragments may not be detected (as a size reduction) on gel fragments of over 500-600 bp. This can be overcome by using amplifying oligonucleotides that produce fragments that overlap by $100 \mathrm{bp}$.

A second approach is the use of denaturing gradient gel electrophoresis (8), which again appears to detect all possible mutations. A recent report has used this method to screen the promoter region of the LDL-R for mutations in FH patients, but none were identified (9). The third method is called SSCP and is based on the fact that single base changes result in conformational changes in single-stranded DNA that can be detected as a different pattern of migration on a polyacrylamide gel (10). DNA fragments are labelled by inclusion of ${ }^{32} \mathrm{P}$ deoxycytidine triphosphate in the amplification mixture and subsequent detection by $x$-ray film. The advantage of this method is that it is rapid and does not use toxic chemicals or require a hybridization step, but it is not yet clear whether it detects all single base changes. The frequency of such "false negatives" has been reported to be low in one study (11), but this probably depends on the specific sequence or base composition of the DNA being studied, and the procedure may not be equally efficient for all genes or all exons of the same gene. To attempt to overcome this problem, different SSCP gels are run with varying conditions of tempera- 
ture and gel porosity. As with chemical cleavage of mismatched bases, the ability to detect differences in the migration pattern is reduced in fragments over $300-400 \mathrm{bp}$. Over the last year, we have used this method to detect sequence changes in the apo $B$ and LPL gene (12), and an example of this method to detect mutations in the $3^{\prime}$ half of exon 4 of the LDL-R gene is shown in Figure 1 (13). DNA samples were available from patients with five different mutations in this part of the gene, including a 3-bp and a 2-bp deletion, and three different single base substitutions. All of these gave a pattern of fragments distinguishable from that seen with normal DNA.

Once a sequence change in a gene has been identified by these methods, direct sequencing of amplified DNA can be used (14) to determine the precise change and its potential effect on the function of the protein. This may be confirmed by expression of the protein in vitro and appropriate assays of function. The next stage would be to develop screening methods to identify relatives of the proband or individuals in other families who are carriers of the mutation. A number of PCR-based methods are available for such screening that do not require radiolabeled probes, but rely instead on fluorescence (15) or chemoluminescence (16). This can be carried out directly where the mutation creates or destroys a restriction enzyme site in the gene by separating the different sized amplified DNA fragments by gel electrophoresis (17), or by the amplification refactory mutation system method using differential amplification oligonucleotides $(18,19)$. Alternatively, sequence differences can be detected in a few hours by allele-specific oligonucleotide melting with, for example, biotinylated oligonucleotides and streptavidin conjugated with horseradish peroxidase and an appropriate chromogenic system (20). Reagents for such detection systems are commercially available; the labeled probe is stable for many months and thus is suitable for use in a routine diagnostic laboratory. For mutations that occur with low frequency, a "pooling" strategy may be appropri-

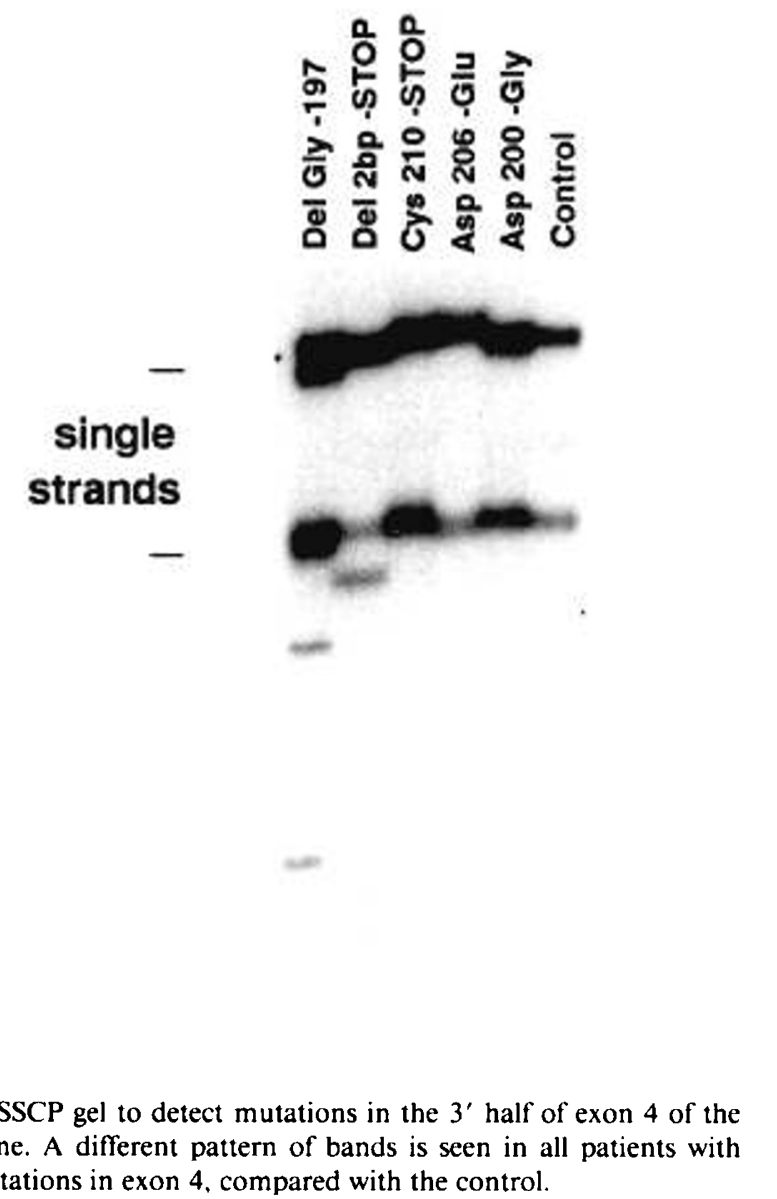

Fig. 1. SSCP gel to detect mutations in the $3^{\prime}$ half of exon 4 of the LDL-R gene. A different pattern of bands is seen in all patients with known mutations in exon 4, compared with the control. ate. Small volumes of whole blood (or DNA isolated by rapid methods from Guthrie blood spots) can be pooled, for example, in batches of 10 , and these batches are then pooled in a cumulative fashion. Using PCR methods, the detection of one variant allele in 100 (i.e. 50 samples pooled) has been reported (21), and in the future new methods may result in greater sensitivity. Such pools of DNA can be efficiently screened for many rare mutations in different genes, and the relevant individuals can be easily identified by rescreening the subpools.

\section{MUTATIONS AFFECTING PLASMA TRIGLYCERIDE LEVELS}

$L P L$. LPL is a heparin-releasable enzyme, bound to glycosaminoglycan components of the capillary endothelium, with a central role in lipid metabolism $(22,23)$. LPL is found in a variety of tissues, including muscle, adipose tissue, and macrophages. It is a glycoprotein and is active as a dimer of two identical subunits each of approximate molecular weight 60000 . LPL, which has an essential requirement for an apoprotein cofactor apo CII, hydrolyzes TG in large TG-rich lipoproteins (chylomicrons and VLDL) (reviewed in 22, 23). The three dimensional structure of human LPL has been deduced by comparison with the $x$-ray crystallography data obtained from the highly homologous human pancreatic lipase (24). The amino terminal two thirds of the protein contain the catalytic triad in a mostly parallel $\beta$-sheet structure, with the catalytic triad residues Asp $_{156}$, His $_{241}$, and $\operatorname{Ser}_{132}(25,26)$ being buried in a hydrophobic pocket covered by a surface loop comprising residues 238-262, which is rotated away as part of the interaction of the enzyme with the lipid substrate. The carboxy-terminal domain consists mainly of antiparallel $\beta$-sheet structures and is thought to have a major function in lipid binding (27). The region that interacts with the apo CII cofactor is thought to be within the N-terminal portion of the protein, although the precise location has yet to be determined (28). There is evidence to suggest that binding to heparin is conferred by residues in the regions 290-300 (29).

The gene for LPL has been located to the short arm of chromosome $8(30)$, and cDNA sequence and the gene structure have been elucidated (31-34). The gene spans about $30 \mathrm{~kb}$ and contains 10 exons coding for a 475-amino acid protein including a 27-amino acid signal peptide; exon 10 codes for the entire $3^{\prime}$ untranslated region. Several RFLP in the LPL gene have been reported including a $P v u I I$ RFLP in the intron between exons 6 and 7 (35) and a HindIII RFLP in the intron between exons 8 and 9 (36). Neither of these RFLP alters any amino acids of the enzyme. One polymorphism that does lead to a change in the amino acid sequence is a $C$ to $G$ transversion at nucleotide 1595 of the cDNA sequence (37) (the Ser $_{447}$-Stop substitution) causing production of a protein truncated by two amino acids. Current evidence suggests this truncated protein maintains normal enzyme activity $(38,39)$ but may have altered lipid binding properties and thus substrate specificity (38).

In recent years, over 30 nonsense or missense mutations or deletion/rearrangements have been described in the gene for LPL (40-46, reviewed in 47) in patients with chylomicronemia syndrome (23) (type I hyperlipidemia). This disorder is characterized by extreme plasma levels of TG resulting in "creamy" plasma and pancreatitis and is usually diagnosed in childhood. In the absence of TG hydrolysis, chylomicrons are not converted to remnants, and thus cannot be recognized by specific lipoprotein receptors and consequently accumulate in the plasma. The phenotype is caused occasionally by a defect in apo CII, the essential cofactor for LPL, but more usually by homozygosity for defects in LPL itself (23). The amino acids of the catalytic triad of the enzyme are encoded in exons 4-6 of the gene and, as shown in Figure 2, many of the reported mutations are clustered in these exons and appear to effect the conformation of the predicted secondary structure or the hydrophobic nature of the pocket surrounding these important residues. Many of the patients reported to date are compound heterozygotes, but this 

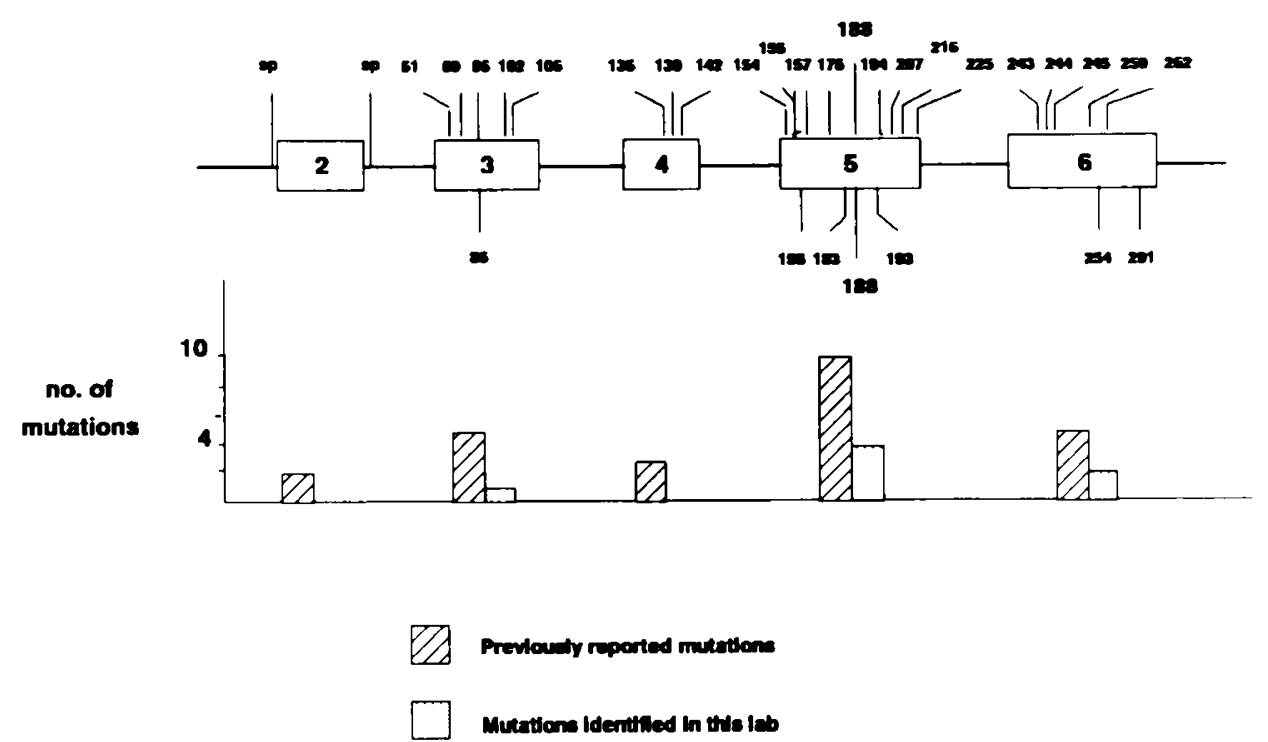

Fig. 2. Map of the LPL gene showing approximate positions of the previously reported mutation and those detected in the work of Mailly et al. (12) in patients from the United Kingdom and other European countries. The boxes represent the exons of the LPL gene. Exons are numbered 1 (the $5^{\prime}$ most exon) to 10 (the $3^{\prime}$ most exon), with only 2-6 shown.

is not the case in those populations where a single mutation occurs frequently because of a "founder" effect, for example, in patients of French-Canadian origin where a Pro P07 $_{2}$-Leu change is common (45). Interestingly, one mutation that results in the substitution of $\operatorname{Gln}_{188}$ with Glu has been found in patients from many different countries, including those from Europe, Asia, and the Indian subcontinent (46). This suggests that this mutation is of ancient origin, possibly predating the divergence of the major ethnic groups. We have been examining a group of 20 patients with type I hyperlipidemia from the United Kingdom and Europe by using the SSCP method to screen exons 2-6 for mutations (12). To date, out of the 40 mutant alleles in this group of patients, a mutation has been identified in 27 alleles, and with the exception of the Gly ${ }_{188}$-Glu mutation, all occurred only in a single family. None of the mutations have been reported previously, and their effect on lipase activity is being determined in expression studies. Overall in this sample, the Gly ${ }_{188}-\mathrm{Glu}$ mutation has been found in 12 of 40 mutant alleles, but among Caucasian patients only, it explained 12 of 26 mutant alleles, or roughly $50 \%$. It would seem likely that this mutation is therefore the most common mutation in patients in the United Kingdom and may be present in the general population at an appreciable frequency. The prevalence of type I hyperlipidemia is hard to estimate, but it is at least as common as homozygous FH (one per 1000000 ), suggesting a carrier frequency for mutations causing LPL deficiency of roughly one per 500 in the general population. If $50 \%$ of these defects are caused by the Gly ${ }_{188}-\mathrm{Glu}$ mutation, it is possible that the frequency of this single defect may be as high as one per 1000 individuals.

Clinical relevance and future research. Although there have now been a large number of reports of specific defects in different patients with type I hyperlipidemia, there has been no attempt to date to compare the severity of hyperlipidemia or clinical symptoms in these different individuals. Our preliminary evidence from the sample of 20 patients suggests those with the Gly $_{188}$-Glu mutation have the typical pattern found in this disorder with severe symptoms, often showing signs of pancreatitis shortly after birth and developing xanthomas, with plasma TG levels of $20 \mathrm{mmol} / \mathrm{L}$ or greater. They respond well to appropriate dietary treatment, with resolution of all clinical symptoms. Biochemical studies on postheparin plasma from these individuals and in vitro expression studies (46) have shown that this mutation results in LPL dimers that are extremely unstable, with the result that the patient has virtually undetectable levels of LPL mass and activity. By contrast, there are other mutations that have been reported in patients with type I that have a much less severe effect on lipase activity. For example, one of the patients we have examined is homozygous for a novel mutation that changes $\mathrm{Ala}_{158}$ to $\mathrm{Thr}$, and this individual shows about $10 \%$ of normal postheparin lipase activity (12), which is significantly higher than the activity found in the patient with the Gly ${ }_{188}-$ Glu mutation. Interestingly, neither of the affected children in the family has ever reported pancreatitis or xanthomas and their hyperlipidemia has been easily resolved by moderate adherence to dietary recommendations. In the future, as more information is known about the relationship between specific mutations and their effect on lipase function, it is likely that more differences will be reported on the effect of different mutations, and this information may be useful in clinical management.

One of the important aspects of LPL deficiency is whether carriers for a mutation in the lipase gene have an elevated risk of developing familial combined hyperlipidemia. This is a disorder first described in the early 1970s with an estimated prevalence in the general population at least two or three times higher than that of carriers for FH and a strong association with increased risk of coronary artery disease $(48,49)$. It is characterized by elevated cholesterol or TG in a proband and relatives, with the primary mechanism thought to be overproduction of apo Bcontaining lipoproteins from the liver $(50,51)$. To date, the molecular defects underlying this disorder are not understood, although in some patients, mutations in the apo AI-CIII-AIV gene cluster have been implicated $(52,53)$. Several lines of evidence suggest that low lipase activity, either genetic or acquired, may be involved in causing the combined hyperlipidemia pattern in at least a subset of individuals. The first comes from investigations of the relatives of probands with type I hyperlipidemia, where it was found that carriers of the Gly ${ }_{188}$-Glu mutation were prone to hypertriglyceridemia, with high plasma levels of apo B and low HDL cholesterol concentrations. The effect of the mutation was modulated by age, with the largest effects being noted in individuals over 40 y (54). Similar results have been reported from the large French-Canadian kindred with the Pro ${ }_{207}$ Leu change (45). The second line of evidence comes from studies in patients with familial combined hyperlipidemia, where LPL mass and activity have been measured with accurate assays. Roughly a third to a fifth of these individuals have levels of activity and mass below the 10th percentile for their age and gender $(55,56)$, suggesting heterozygosity for an allele that codes 
for a defective LPL enzyme. This might predispose an individual to a defective clearance of TG-rich lipoproteins, which could develop into the full pattern of combined hyperlipidemia when other environmental or genetic factors result in VLDL overproduction or LPL down-regulation, which saturates this reduced clearance system. Two recent reports have suggested possible mechanisms to explain how low LPL levels could result in overproduction of apo B-containing lipoprotein from the liver, but the precise mechanism is not yet established $(57,58)$.

There still remain several unresolved questions about the mechanism of the association between factors that cause an individual to have low levels of LPL activity and the subsequent development of hyperlipidemia. However, the data so far suggest the strong possibility that individuals who are carriers for a mutation in the LPL gene may benefit from an early identification of such a risk, followed by appropriate counseling on lifestyle changes that would help them to reduce their subsequent risk, and more detailed monitoring so that if they should develop hyperlipidemia at a later age they could be given appropriate therapeutic advice. Thus, although being a carrier for a mutation in the LPL gene does not require immediate pediatric treatment, such information may be useful in adulthood for the individuals identified and may be of immediate use for their relatives.

Apo CII. Apo CII is a 79-amino acid protein that acts as a cofactor for the activation of LPL (reviewed in 59). The gene spans $3.32 \mathrm{~kb} \mathrm{(60)}$ and is part of the apoprotein gene cluster on chromosome 19 together with apo $\mathrm{E}$, apo $\mathrm{CI}$, and the apo $\mathrm{CI}$ pseudogene (61). Apo CII, apo E, and apo CI show strong sequence homology and a similar intron/exon arrangement reflecting their evolution from a common progenitor (62). Three functional domains of apo CII have been elucidated by studies on synthetic peptides and proteolytic fragments (59) and by studies on the expression of normal and mutated variants of human apo CII in a bacterial system (63). The lipid-binding domain, between residues 14 and 50 , consists of three amphipathic $\alpha$-helices that anchor the molecule to the lipoprotein surface. The LPL-activation domain consists of residues 55-65 at the carboxy-terminal third of the protein, whereas the LPLbinding domain is residues $65-79$, on the basis of the predicted amphipathic helix structure of this part of apo CII (59) and including the charged terminal tetrapeptide.

In some individuals with type I hyperlipoproteinemia. LPL is normal and the disorder is caused by a defect in apo CII $(24,64$, 65). Apo CII deficiency is extremely rare, with a frequency considerably lower than LPL deficiency, but the clinical expression of the two are very similar, both being characterized by massive fasting chylomicronemia and recurrent pancreatitis. The pattern of inheritance of the clinical phenotype of apo CII deficiency is recessive, with obligatory heterozygotes having half normal apo CII levels but normal lipid levels. To date, 14 apo CII-deficient families have been identified worldwide and, as shown in Table 1, the mutation in eight families has now been elucidated. The defect can be caused either by frameshift mutations due to insertions or deletions, by base substitutions that create a premature stop codon or alter a donor splice site, or by a single base change in the initiation codon (72). All these mutations have a profound effect on either the structure or the amount of apo CII in the plasma. To date, no single amino acid substitution leading to loss of apo CII function has been reported, and in all but two families (73) the mutations are unique.

Clinical relevance and future research. So far there are no data to suggest that different mutations in apo CII might be associated with different clinical consequences or that the dietary management of type I hyperlipidemia caused by apo CII deficiency should be different from that caused by LPL deficiency, although there is general agreement that type I caused by apo CII deficiency is usually associated with milder symptoms (23). This may be in part because, even in the complete absence of apo CII, LPL still has some residual activity $(27,59)$, and thus some lipoprotein metabolism occurs. However, the extreme rarity of
Table 1. Mutations in apo CII gene causing type I hyperlipoproteinemia

\begin{tabular}{|c|c|c|}
\hline Variant & Mutation & Effect on apo CII \\
\hline Apo $\mathrm{CII}_{\text {Toronto }}{ }^{66}$ & $\mathrm{~T}$ deletion $\rightarrow$ frameshift & $\begin{array}{l}\text { 74-amino acid pro- } \\
\text { tein-last }\end{array}$ \\
\hline Apo $\mathrm{CII}_{\text {St. Michael }}{ }^{67}$ & $\begin{array}{l}\text { Leu }_{75} \rightarrow \text { stop } \\
\text { Single base insertion } \\
\text { codon }{ }^{66} \text { or } \rightarrow \\
\text { frameshift }^{67}\end{array}$ & $\begin{array}{l}6 \text { residues abnormal } \\
96 \text {-amino acid protein } \\
\text { Residues } 71-96 \text { abnor- } \\
\text { mal }\end{array}$ \\
\hline Apo $\mathrm{CII}_{\text {Hamburg }}{ }^{6 *}$ & $\begin{array}{l}\mathrm{G} \rightarrow \mathrm{C} / \text { intron } 2 \text { donor } \\
\text { splice defect }\end{array}$ & No protein synthesized \\
\hline Apo $\mathrm{Cll}_{\text {Nymegen }}{ }^{69}$ & $\begin{array}{l}\mathrm{G} \text { deletion } \rightarrow \text { frameshift } \\
\mathrm{Val}_{18} \rightarrow \text { stop }\end{array}$ & No protein synthesized \\
\hline Apo $\mathrm{CII}_{\text {Padova }}{ }^{70}$ & $\mathrm{C} \rightarrow \mathrm{A} / \mathrm{Tyr}_{37} \rightarrow$ stop & $\begin{array}{l}\text { Truncated protein } 36 \\
\text { amino acids long }\end{array}$ \\
\hline Apo $\mathrm{CII}_{\mathrm{Bari}}{ }^{71}$ & $\mathrm{C} \rightarrow \mathrm{G} / \mathrm{Tyr}_{37} \rightarrow$ stop & $\begin{array}{l}\text { Truncated protein } 36 \\
\text { amino acids long }\end{array}$ \\
\hline Apo $\mathrm{ClI}_{\text {Paris } 1}{ }^{64}$ & $\begin{aligned} \mathrm{A} & \rightarrow \mathrm{G} / \text { Initiation } \mathrm{Met}_{22} \\
& \rightarrow \mathrm{Val}\end{aligned}$ & No protein synthesized \\
\hline Apo CII $_{\text {Pars } 2} 2^{64}$ & $\mathrm{C} \rightarrow \mathrm{T} / \operatorname{Arg}_{19} \rightarrow$ stop & No protein synthesized \\
\hline Apo $\mathrm{CII}_{\text {venezucla }}{ }^{3}$ & C deletion codon 2 or 24 & No protein detected \\
\hline Apo $\mathrm{CII}_{\mathrm{Japan}^{73}}$ & C deletion codon 23 or 24 & No protein detected \\
\hline
\end{tabular}

apo CII deficiency makes any such comparison difficult and any definite conclusion must await further data. There is also little evidence to indicate any strong association between the carrier status for apo CII deficiency and hyperlipidemia. One study reporting recently on a large kindred from Toronto (74) indicated that carriers for apo CII deficiency who are also heterozygous for the apo E4 allele of apo E that is associated with elevated levels of plasma lipids have significantly higher levels of TG and lower HDL cholesterol than relatives with apo CII deficiency and other apo $\mathrm{E}$ isoforms. Although this is a very informative example of how genetic variations at two different loci, coding for proteins that are both involved in lipid metabolism. may interact to determine an individual's plasma lipid levels, the low frequency of the apo CII deficiency makes this not of immediate clinical relevance.

\section{MUTATIONS AFFECTING LEVELS OF PLASMA CHOLESTEROL}

Apo B. Apo B is the sole protein component of $\mathrm{LDL}$ and therefore the principal cholesterol-transporting protein. The mature apo B100 protein is 4536 amino acids long (75) and is secreted from the liver and found in VLDL, intermediate density lipoproteins, and LDL. Amino acid sequence comparisons with the receptor-binding domain of apo $\mathrm{E}(76)$ and from studies with MAb that inhibit binding of LDL to the LDL-R (77) suggested that the region encompassing amino acids 3359-3780 is responsible for the interaction with the receptor. There is a second. shorter form of apo B (B48) that is associated with chylomicrons and secreted from the intestine. The apo B48-containing chylomicron remnants are rapidly cleared from the circulation, whereas the apo B 100 containing particles are partially metabolized to LDL that has a relatively long half-life in the circulation. The receptor binding region of apo B is absent from apo B48, and it has been suggested that this may have evolved to ensure the rapid delivery of the remnant particles of dietary lipid to the liver mediated by apo E binding to the LDL-R or the remnant receptor.

There is a single apo B gene on chromosome 2 (p23-p24) (78). The gene contains 29 exons spanning $43 \mathrm{~kb} \mathrm{(62),} \mathrm{and} \mathrm{its} \mathrm{intron/}$ exon organization is very different from that of the other apoprotein genes, suggesting a different evolutionary history. The intriguing question of how both the liver and intestinal forms of apo $B$ are synthesized from the same gene has now been elucidated. The intestinal apo B48 form of apo B has been shown to be colinear with the amino terminal half of apo B100 and 
terminates at isoleucine $e_{2152}$ of apo $\mathrm{B} 100$ as the result of the introduction in the mRNA of a $\mathrm{C} \rightarrow \mathrm{U}$ transition at nucleotide 6666 that creates a stop codon and results in protein termination (79). This apo B mRNA editing mechanism is under tissuespecific and developmental regulation (80). Because apo B48 lacks the sequence that is required for interaction with the LDL-R, the differential expression of the two forms of apo $B$ is important in directing the metabolism of lipoproteins.

$A B L$. Two primary disorders of lipoprotein metabolism exist, characterized by a complete absence or deficiency in apo Bcontaining lipoproteins. These are $\mathrm{ABL}$ and $\mathrm{HBL}$ (75). $\mathrm{ABL}$ is inherited as an autosomal recessive disorder, with heterozygous parents having normal lipid levels, whereas affected individuals have trace amounts of apo B-containing lipoproteins in the plasma and this is associated with the clinical symptoms of fat malabsorption, acanthocytes, retinitis pigmentosa, and muscular neuropathies (75). Most of the neuropathies are caused by the deficiency of fat-soluble vitamin $A$ and $E$ transportation by the chylomicrons, and once identified, these individuals can be treated very successfully by appropriate dietary measures and vitamin supplements (81). Mutations in the apo B gene would be an obvious possibility for causing this disorder, but because there is a single apo $\mathrm{B}$ molecule per $\mathrm{LDL}$ particle, it can be postulated that defects in the apo B gene would be expressed in a codominant fashion, with half the circulating LDL having the normal apo B protein and half having the abnormal variant of apo $B$. Thus, the recessive inheritance of $A B L$ suggests strongly that the mutation may be in a gene other than that for apo $B$. In addition, a study carried out on liver biopsies from two patients with ABL showed that apo B mRNA could be easily detected, and that levels were 8-fold enhanced (82) and immunohistologic techniques have shown that apo $B$ accumulates within both hepatocytes and enterocytes in this disorder $(83,84)$. This suggests that the defect is most likely in a gene involved in posttranslational modification or secretion of apo B. Genetic confirmation of this, ruling out the apo B gene as a candidate, was obtained by cosegregation studies such as those shown in Figure 3. For a recessive disorder caused by a mutation in the apo $B$ gene, all affected children in a family should have the same genotype at the apo B locus, having inherited the same defective allele from each of their parents, as shown in family I. The results obtained from several families each with two affected children showed the pattern demonstrated in family II with no cosegregation of the apo $B$ gene with $A B L(85,86)$, thus confirming that defects in another gene must be the cause of the disorder. One possibility is that the defect is in a "chaperon" protein that is involved in translocation of the apo B protein from the cystolic compartment or through the Golgi apparatus, where the lipoprotein particle is assembled. The identification of the gene or genes involved in this process will provide valuable insights into the mechanisms

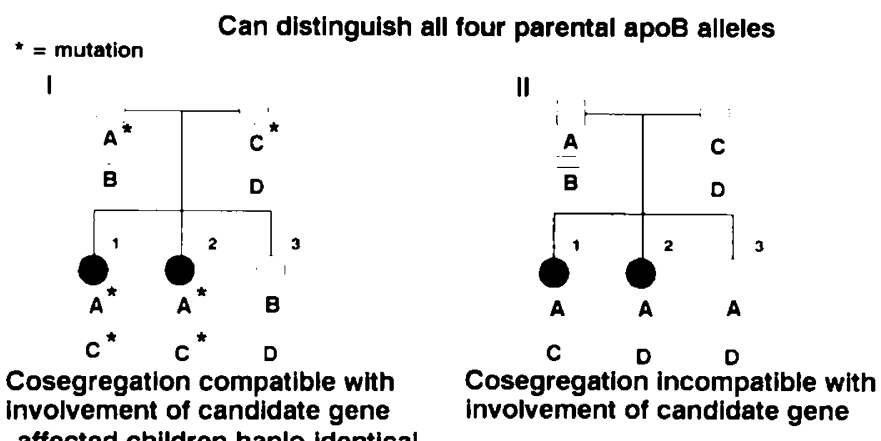

- affected children haplo-identical

Fig. 3. Example pedigrees of families with ABL. $A, B, C$, and $D$ are parental apo B haplotypes. Black symbols-affected. Data from family I would support the possibility of mutations in the apo B gene as being involved in causing ABL. In family II, the two affected children 1 and 2 have inherited different apo $B$ haplotypes, and this excludes cosegregation of $\mathrm{HBL}$ and the apo B gene. Data adapted from Talmud et al. (85). that control secretion of lipoproteins from the liver and intestine, both in this disorder and in individuals in the general population.

$H B L$. In contrast with $\mathrm{ABL}, \mathrm{HBL}$ is inherited as a codominant disorder with heterozygotes having total cholesterol, LDL cholesterol, and apo B levels below the 5th percentile. Cosegregation studies have supported the hypothesis that the mutation is in the apo B gene (87). All mutations identified to date result in truncated proteins and most have been initially detected at the protein level using PAGE of plasma or LDL to estimate protein size. Further identification and sizing of truncations have been achieved with immunoblots and binding with MAb with welldefined epitopes. In a recent screening carried out on blood donors in St. Louis, the frequency of familial HBL was estimated to be less than $0.01 \%(88)$. In the homozygous form, patients have trace levels of apo B-containing lipoproteins and the clinical characteristics of ABL. More than 15 truncated apo B mutations causing HBL have now been characterized at the molecular level (Table 2). A map of the apo B gene showing the position of some of the mutations that lead to truncated proteins is shown in Figure 4. Except in the case of apo B25, the result of a deletion of the entire exon 21, all the truncated forms reported to date are caused by $\mathrm{C} \rightarrow \mathrm{T}$ transitions or base deletions. In addition, all the reported mutations have been unique to the kindreds they have been identified in and no two unrelated families have had the same mutation.

These truncated apo B species have helped define the functional domains of apo B, namely the lipoprotein assembly, lipid binding, and receptor binding regions. Where the mutation creates a protein greatly reduced in size. for example, the truncated apo B species apo B25 (89) and apo B29 (90), no plasma apo B was detected. It has been suggested that these small truncated species lack a domain necessary for lipoprotein association and stability. The amino acid residues in the amino terminus of the protein are hydrophilic and would not bind well to lipid. The truncated species apo B31 (91) and apo B37 (92) are associated with small amounts of TG-rich lipoproteins and occur primarily in the HDL density range; this reflects the small amount of associated lipid and not an HDL-type particle. These conclusions have been confirmed by in vitro expression studies $(101,102)$. Taken together these results suggest that the hydrophobic amino acids found between apo B31 and apo B39 are necessary for assembly and secretion of apo B-containing lipoproteins. Thus, there appears to be a critical size that the protein must excede to associate with lipid, with truncated apo B proteins smaller than apo B31, although detected in the plasma, being very unstable and rapidly degraded after secretion. Apo B46 (94), apo B50 (95), and apo B54.8 (88) are found primarily in the VLDL density range, although apo B46 is seen in LDL and HDL ranges and apo $\mathrm{B} 54.8$ in the LDL density range. The larger apo B species, apo B86 (99), apo B87 (100), and apo B89 (103) are found in a similar density range as full-length apo B100. Thus, the truncated apo B proteins help define the region in the amino terminal end of the protein important in the association with lipids (Table 3, Fig. 4).

The low levels of these truncated forms in the plasma are the result of several different mechanisms. Most of the truncated apo $B$ proteins lack the portion of the protein that binds to the LDL receptor; thus an increase in receptor-mediated catabolism is unlikely to be an explanation for the low concentrations of apo $B$, and it is probable that the instability of the mutant lipoproteins is the major contribution to their low levels. The larger truncated proteins apo B87 and apo B89, which do encode the primary LDL-R binding domain, provide evidence of secondary binding domains on apo B for the LDL-R. In the case of the apo B89, degradation was increased in cultured fibroblasts compared with apo B100 (103), and in addition there was enhanced clearance of apo B89 in LDL turnover studies performed in rabbits (104). This suggests that apo B89 has an increased affinity for the LDL-R, thus explaining the low concentration of apo B89 in the plasma of the original patient (103). 
Table 2. Characteristics of truncated apo B species associated with $H B L$

\begin{tabular}{|c|c|c|c|}
\hline & Mutation & $\begin{array}{l}\text { Predicted no. } \\
\text { amino acids }\end{array}$ & Density fractions \\
\hline Apo $\mathrm{B} 25^{89}$ & Deletion exon 21 & 1085 & None \\
\hline Apo B2990 & $\mathrm{C} \rightarrow \mathrm{T} \mathrm{Arg}_{1036} \rightarrow$ stop & 1305 & None \\
\hline Apo B31 91 & Deletion $\mathrm{G}_{4480} \rightarrow$ frameshift & 1425 & $\mathrm{HDL}+$ infranatant \\
\hline Apo $\mathrm{B} 37^{92}$ & Deletion AACA $\rightarrow$ frameshift $_{5391-5394}$ & 1728 & VLDL, LDL, HDL \\
\hline Apo $\mathrm{B} 39^{90}$ & Deletion $G_{5591} \rightarrow$ frameshift & 1799 & VLDL, LDL \\
\hline Apo $\mathrm{B} 40^{93}$ & Deletion $\mathrm{TG}_{5693-5964} \rightarrow$ frameshift & 1829 & VLDL, LDL, HDL \\
\hline Apo B46 $6^{94}$ & $\mathrm{C} \rightarrow \mathrm{T} \mathrm{Arg} 2058 \rightarrow$ stop & 2057 & VLDL, LDL, HDL \\
\hline Apo B5095 & $\mathrm{C} \rightarrow \mathrm{T} \mathrm{G} \ln _{2252} \rightarrow$ stop & 2251 & VLDL \\
\hline Apo B54.8 $8^{88}$ & $\mathrm{C} \rightarrow \mathrm{T} \mathrm{Arg} 2486 \rightarrow$ stop & 2485 & VLDL, LDL \\
\hline Apo B55 ${ }^{96}$ & $\mathrm{C} \rightarrow \mathrm{T} \mathrm{Arg} 2495 \rightarrow$ stop & 2494 & VLDL, LDL \\
\hline Apo B6 $1^{97}$ & Deletion 7 bases $\rightarrow$ frameshift ${ }_{8525-8561}$ & 2784 & VLDL, LDL \\
\hline Apo $B 67^{98}$ & Deletion nucleotide $_{9327} \rightarrow$ frameshift & 3040 & VLDL, LDL \\
\hline Apo $\mathrm{B}^{8} 6^{99}$ & Deletion nucleotide $_{11840} \rightarrow$ frameshift & 3896 & VLDL, LDL \\
\hline Apo $B 87^{100}$ & Deletion nucleotide $_{12032} \rightarrow$ frameshift & 3979 & VLDL, LDL \\
\hline Apo B89 $9^{93}$ & Deletion nucleotide $\mathrm{G}_{12032} \rightarrow$ frameshift & 4039 & VLDL. LDL \\
\hline
\end{tabular}

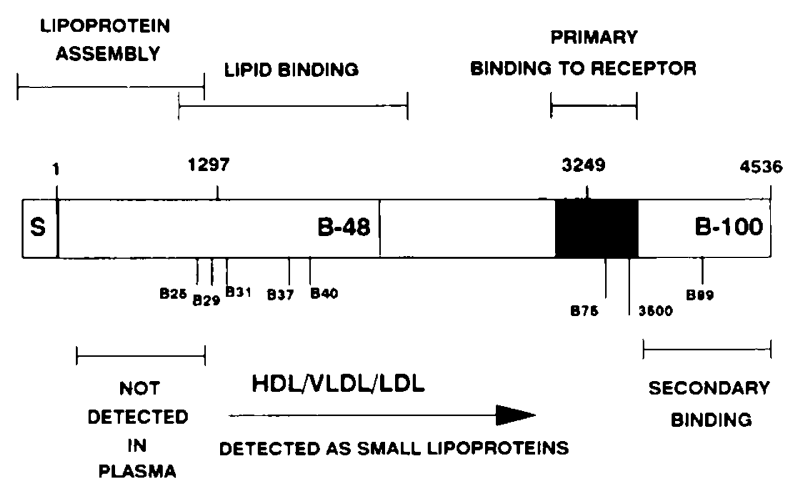

Fig. 4. Schematic map of the apo B cDNA identifying reported mutations that lead to HBL. The black box depicts the proposed LDL$\mathrm{R}$ binding domain. $S$ shows the signal peptide of the protein.

Other truncations in this region of the protein have been reported with a similar increase in receptor-mediated catabolism (100). Thus, the absence of the carboxyl-terminal 500 amino acids, which are hydrophobic and firmly embedded in lipid, may result in the release of the constraint put on the primary receptor binding domain or make more available a secondary region around amino acids $4001-4019$ (105), resulting in an increased catabolism of the LDL.

Clinical relevance and future research. There is some evidence to support the view that different mutations in $\mathrm{HBL}$ are associated with different clinical consequences. The extent of the severity appears to be related to the size of the truncated apo B protein and whether it can associate with lipid; for example, the patient with homozygous HBL, homozygous for an apo B25, presented with symptoms of ABL (89). However, several compound heterozygous patients $(92,103)$ were asymptomatic, and in these cases at least one truncated apo B protein was capable of associating with lipid, thus participating in fat-soluble vitamin transportation. Further research is required to explore whether there are different clinical consequences in later life associated with these different classes of truncations, for example the onset of neuropathy or retinopathy (96). It is still unclear, however, why some heterozygous $\mathrm{HBL}$ patients have LDL levels below the 5th percentile and not at the 50th percentile despite the presence of one normal apo B100 allele. Some insight comes from LDL turnover studies in $\mathrm{HBL}$ patients. LDL turnover studies performed on a patient with apo B55 revealed a reduced LDL synthetic rate $(5.5 \mathrm{mg} / \mathrm{dL} / \mathrm{d})$ compared with the normal range of $10-15 \mathrm{mg} / \mathrm{dL} / \mathrm{d}(106)$, confirming results from an earlier study (107) that showed a reduced LDL synthetic rate and a reduced synthetic rate of VLDL-apo $B$ in two HBL patients,

Table 3. Summary of mutations in LDL-R gene in 200 patients with FH in United Kingdom

\begin{tabular}{|c|c|c|c|}
\hline Type of mutation & $\begin{array}{l}\text { No. of } \\
\text { unrelated } \\
\text { patients }\end{array}$ & Comments & Reference \\
\hline \multirow[t]{2}{*}{$\begin{array}{l}\text { Deletions/rearrangements detected by } \\
\text { Southern blotting }\end{array}$} & \multirow[t]{2}{*}{9} & $\begin{array}{l}4 / 9 \text { same as and } 3 / 9 \text { similar } \\
\text { to previously detected mu- } \\
\text { tations }\end{array}$ & 151.152 \\
\hline & & $\begin{array}{l}\text { 1/9 insertion complementary } \\
\text { to previously described } \\
\text { deletion }\end{array}$ & 152 \\
\hline Glu $_{80} \rightarrow$ Lys (exon 3$)$ & 5 & Probably same allele & 150 \\
\hline \multicolumn{4}{|l|}{ Exon 4 mutations } \\
\hline Deletion of $\mathrm{Gly}_{197}$ & 6 & Common in Lithuanian Jews & 149 \\
\hline Deletion of 2 bp in codons $206 / 207$ & 5 & $\begin{array}{l}\text { Same allele in all; "English" } \\
\text { defect }\end{array}$ & 149 \\
\hline $\mathrm{Cys}_{210} \rightarrow$ stop & 1 & Irish/Scottish patient & 149 \\
\hline $\mathrm{Asp}_{206} \rightarrow \mathrm{Glu}$ & 3 & Same as common Afrikaner & 146 \\
\hline $\operatorname{Ser}_{1 s 6} \rightarrow$ Leu & 1 & $\begin{array}{l}\text { Same as Puerto Rico, but re- } \\
\text { current mutation }\end{array}$ & 154 \\
\hline Asp $200-G l y$ & 1 & New: English origin & 13 \\
\hline Pro $_{664} \rightarrow$ Leu (exon 14 ) & 5 & Recurrent mutation & 153 \\
\hline Total & 36 & ( $18 \%$ of mutant allele) & \\
\hline
\end{tabular}


where the molecular defect is unknown. These data support the view that a reduced synthetic rate of VLDL occurs in these patients and thus the synthetic rate of LDL containing both the truncated and the normal apo B100 may be reduced. Apo B synthesis is constitutive in liver cells, and overall the output of apo $B$ is controlled by changes in the mRNA translational efficiency, or more likely by changes in degradation of intracellular apo B in response to endogenous factors such as the level of plasma fatty acids or postprandially (108). Thus, it is possible that in the hepatocytes of the heterozygous HBL patients, although mRNA coding for both the truncated and normal apo B proteins are translated, the truncated species interferes with the assembly of apo B100 into normal lipoproteins, leading to an overall reduction in secretion of apo B-containing lipoproteins. Further research to explore such mechanisms should lead to a better understanding of the control of secretion of apo B-containing particles from the liver.

$F D B$. It is well known that defects in the LDL-R that destroy function lead to FH. Similarly, hypercholesterolemia could be caused by defects in the apo B gene that would reduce binding to the LDL-R and lead to raised cholesterol levels, and the name FDB has been proposed for such mutations (109). A number of laboratories have carried out systematic searches, using molecular biology techniques, to identify patients who have mutations in the apo B gene that would alter receptor binding. To date, there is only one form of FDB and that is caused by a mutation that substitutes codon $\operatorname{Arg}_{3500}$ with Gln (110), thus it is called the apo B3500 mutation. Originally observed in a patient who showed reduced clearance of autologous LDL compared with clearance of LDL from a normal donor (111), the mutation was identified as a $G \rightarrow A$ substitution altering codon $C G G$ to $C A G$ (112). This single amino acid change reduces binding of the LDL containing apo B-Gln ${ }_{3500}$ resulting in the accumulation of such LDL (109), whereas LDL-Arg ${ }_{3500}$ is cleared with normal efficiency. In some patients, it has proved possible to separate the two species of LDL using binding to MAb (113). Purified LDL$\mathrm{Gln}_{3500}$ has $5 \%$ normal receptor binding affinity and thus accumulates in vivo; in an FDB heterozygote, as much as $70 \%$ circulating LDL will be LDL-Gln ${ }_{3500}$. The mechanism of the effect has been elucidated by studying the differential binding of $\mathrm{MAb}$ and using carbon-13 nuclear magnetic resonance (114), which showed that the six lysine residues within the region of amino acid 3500 have altered ionization constants in the presence of $\mathrm{Gln}_{3500}$. Lysine residues are known to be involved in the binding of apo B100 to the LDL-R, and the substitution of $\operatorname{Arg}_{3500} \rightarrow G i n$, by a large effect on the conformation of the surrounding area of the protein, alters the microenvironment of the receptor binding domain.

To date, only individuals who are heterozygous for the mutation have been identified (115). Individuals with FDB have been identified in the United States, Canada (110), Austria (116), United Kingdom, and Denmark (117), Germany (118), and Italy (119), but not in Finland (120). Haplotype analysis using apo B gene polymorphisms has shown that in all cases reported to date the mutation is identical by descent, and thus all FDB carriers have a common ancestor $(121,122)$. The occurrence of the mutation in ethnic groups, other than Caucasians, has not yet been reported. Rough estimates of the frequency of the mutation in the general population made on the basis of the frequency found in lipid clinic patients are in agreement, ranging from one per 500 (117) to one per 700, (118), but to date, no systematic study to screen for the mutation in the general population has been carried out. The apo B3500 mutation appears to be the most common single gene defect causing hypercholesterolemia. and although other apo B mutations causing FDB may be identified in the future, it is likely that apo B3500 will be the most common.

The mutation was originally identified in a patient who was moderately hypercholesterolemic (111), but three recent studies have screened patients with a clinical diagnosis of $\mathrm{FH}$ and found that roughly $3 \%$ of these patients were heterozygous for the apo B3500 mutation $(117,118,123)$. Where the patients have been analyzed further, this occurred in individuals who had LDL-R activity within the normal range (124). This mutation can be associated with severe hypercholesterolemia, tendon xanthomas, and a family history of premature coronary artery disease, and it is therefore clinically indistinguishable from $\mathrm{FH}$ caused by receptor defects. Furthermore, as with defects in the LDL-R gene, the effect of the apo B3500 mutation on plasma lipid levels can be expressed in children (Fig. 5), with several families (124) now reported with children under the age of $5 \mathrm{y}$ having markedly elevated LDL cholesterol levels.

Clinical relevance and future research. The range of expression of the mutation is of major clinical interest. All carriers of the mutation have LDL that binds with reduced affinity to the receptor, but the absolute levels of LDL cholesterol in the blood and thus the future risk of developing coronary artery disease will depend on the interaction between other genetic and environmental factors. In a recent review of all the published biochemical and clinical information on 70 FDB carriers (125), it was clear that the rate of development of coronary artery disease in this disorder was similar to that reported in $\mathrm{FH}$ patients, with a faster rise in males than females. Over $85 \%$ of carriers have total and LDL cholesterol levels over the 95 th percentile for their age and gender, but unlike FH patients, TG and HDL cholesterol levels are within the normal range. This is presumably because the metabolism of the TG-rich lipoprotein, mediated through apo $E$ and the normal LDL-R, is not affected by the apo $B$ mutation. However, the information regarding the range of clinical severity of the disorder is biased, because to date the majority of patients have been identified by screening individuals attending lipid clinics, many of whom had a clinical diagnosis of $\mathrm{FH}$. This raises the possibility that the mutation may not always be associated with such severe clinical consequences, and in support of this, a review of the published data on plasma lipid levels of relatives $(125)$ shows that some have levels within the normal range for their age and gender. Presumably environmental factors, and variation at other gene loci, will contribute to these individual differences and may possibly interact specifically with the apo B mutation. Although no such data on range of expression is yet available for any of the mutations in the LDL-R gene causing FH, a priori it is likely that a similar range will be seen. It is therefore important to identify FDB carriers

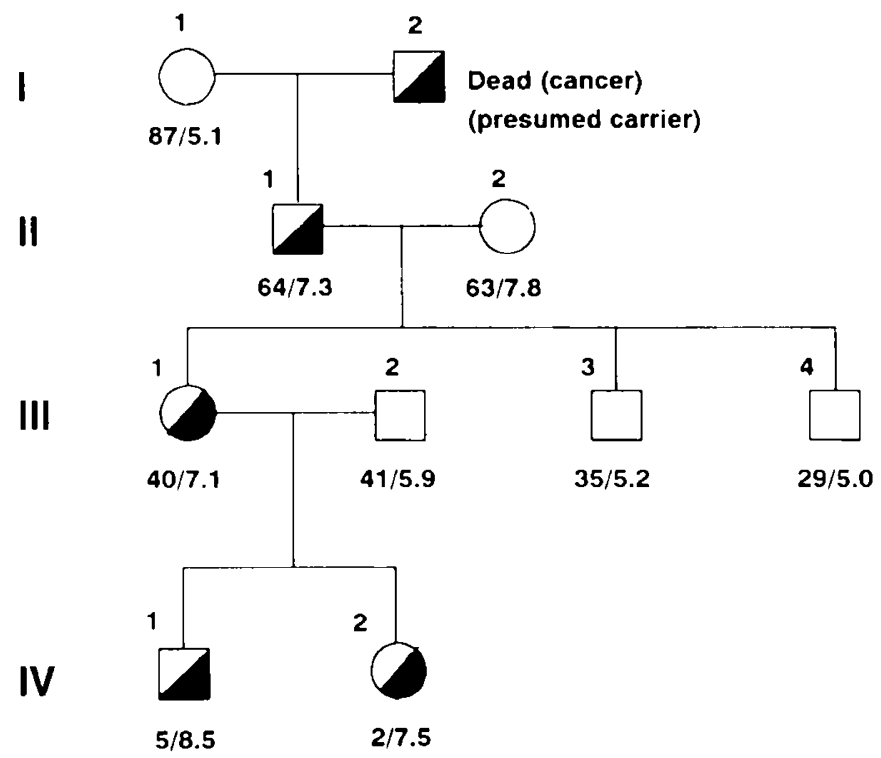

Fig. 5. Pedigree of a four-generation family with apo B3500. Data shown are age and cholesterol levels $(\mathrm{mmol} / \mathrm{L})$ below each member. Generation I-2 is deceased and is a presumed heterozygote. Half-filled symbols-heterozygote for FDB. Data adapted from Myant $e t$ al. (124). 
from the general population to allow an unbiased estimate of the risk of hyperlipidemia and atherosclerosis associated with this defect. Only then can accurate information be given to carriers and appropriate therapeutic management strategies started.

It is still not clear what is the best drug therapy to offer FDB patients. Most conventional drug therapies for $\mathrm{FH}$ rely on upregulation of the LDL-R to enhance clearance of LDL, but the LDL-GIn cannot be cleared by this route and may still accumulate. The atherogenic potential of such accumulating defective LDL is not understood, and it is possible that LDL-Gin may be susceptible to oxidation and it thus may accumulate in foam cells and promote atherosclerosis. Studies have been carried out on FDB patients to examine the responsiveness to drugs (126128 ), and although plasma levels of LDL do fall in most patients, it is possible that this is caused mainly by a reduction in plasma levels of LDL-Arg. Thus, for FDB patients, treatment with antioxidants or a combination treatment may prove a better therapy, and if this were the case, using genetic tests to distinguish hypercholesterolemia caused by a receptor or a ligand defect would be of major importance.

$L D L-R$ defects in $F H$. $\mathrm{FH}$ is a common inherited disease showing an autosomal dominant pattern of inheritance (129). It is characterized clinically by elevation in the concentration of LDL cholesterol in blood, tendon xanthomata, and an increased risk of myocardial infarction. FH is present in 5-10\% of individuals under the age of $55 \mathrm{y}$ in the United Kingdom and the United States who develop coronary artery disease $(130,131)$, and is therefore the best understood single-gene cause of hyperlipidemia and thus atherosclerosis risk. Based on the estimated population frequency of carriers of one per 500, there are more than 100000 FH heterozygous individuals in the United Kingdom, of which probably less than 3000 have been identified to date. Once identified, the hyperlipidemia of these patients is responsive to treatment by diet and drugs $(132,133)$, and such treatment reduces subsequent morbidity and mortality (134). Children who have inherited two defective alleles of the LDL-R (homozygous $\mathrm{FH}$, but usually compound heterozygous for two different defects) represent one per 1 million of the population. In these children, there is usually little useful lowering of plasma LDL cholesterol levels in response to diet or drugs, and many suffer a major coronary event in the first or second decade of life, but life expectancy can be extended by appropriate treatment $(135$, 136). Current treatment is usually plasma exchange or LDL apheresis (137), but patients may alternatively be treated by transplantation of a donor liver, possibly in conjunction with a heart transplant (138)

FH results from different genetic defects in a cell surface receptor that normally controls the uptake of plasma LDL (129, 139). Five classes of mutations at the LDL-R locus have been identified on the basis of phenotypic behavior of the mutant protein (140). Class I mutations fail to produce any immunoprecipitable protein (null alleles). Class II mutations encode proteins that do not fold properly after synthesis and are blocked, either partially or completely, in transport between the endoplasmic reticulum and the Golgi complex (transport defective alleles). Class III mutations encode proteins that are synthesized and transported to the cell surface but fail to bind LDL normally (binding-defective alleles). Class IV mutations encode proteins that move to the cell surface and bind LDL normally, but are unable to cluster in clathrin-coated pits and thus do not internalize LDL (internalization-defective alleles). Class $\mathrm{V}$ mutations encode receptors that bind and internalize ligand in the coated pits, but fail to discharge the ligand in the endosome and fail to recycle to the cell surface (recycling-defective alleles). These different classes of mutations are caused by defects scattered over the entire LDL-R gene in the case of the first two classes, and mutations in the ligand binding region, the cytoplasmic domain, and in the epidermal growth factor precursor homology domain for classes III-V, respectively.

The cloning of the human LDL-R gene (141) has made it possible to study $\mathrm{FH}$ using DNA technology. There have been at least 40 different mutations of the LDL-R gene characterized at the DNA level (140), and they have given valuable insights into the function of the different domains in the LDL-R. Many more mutations are likely to be found, and Hobbs $e t$ al. have postulated from the number of homozygous $\mathrm{FH}$ patients they have investigated that in the Dallas collection alone there could be as many as 183 mutant alleles, although only the minority have been characterized at the DNA level so far (140). Several studies have been published demonstrating that within a geographically or culturally isolated population, or where a large proportion of people are related by descent because of migration, there may be a single mutation causing $\mathrm{FH}$ in many of the patients (142-148). In the United Kingdom, where there is a very heterogeneous population, it is unlikely that any mutations will be present at a high frequency in $\mathrm{FH}$ patients. As part of a collaborative project to study mutations in $\mathrm{FH}$ patients in the United Kingdom, we have recently discovered that two small deletions in exon 4 of LDL-R gene (Table 3 ) are each present at a frequency of $2-3 \%$ in a group of $200 \mathrm{FH}$ patients in London (149). It has also recently been shown that a mutation identified in exon 3 of the gene was present in $2 \%$ of the London sample, but $15 \%$ of a sample of patients from Manchester (150). It is thus possible that even in a heterogeneous population, such as in the United Kingdom, the frequencies of some mutations may be relatively high in certain local areas. Our findings to date in this sample from London are that $3 \%$ have the apo B3500 mutation (117) and $5 \%$ of patients have a gross deletion (151, 152 ), whereas in a further $12 \%$ a small deletion or a single base mutation has been detected in exon 3,4 , or $14(13,150,151$, $153,154)$. Thus, with six DNA tests the specific defect causing $\mathrm{FH}$ can be determined in roughly $20 \%$ of patients from the London sample. These results are extremely encouraging, although either many additional mutations must be found or a different strategy must be developed if DNA methods are ever to become a useful adjunct to classic screening methods. However, the techniques are now available for examining the entire LDL-R gene from a patient with suspected FH in a rapid and accurate way, for example using the SSCP method shown in Figure 1, and once the mutation has been identified, it is likely that this information will be of use in both the management of the patient and identification of relatives.

Clinical relevance and future research. There are a number of clinically important questions about $\mathrm{FH}$ that have not yet been answered, and can be addressed in the next few years using the molecular techniques now available.

DNA tests for identification of FH in relatives. Recently, several overview analyses of the results of published trials of diet and drug therapy to lower lipids in middle-aged high-risk patients. have suggested the possibility of harmful side effects in some individuals (155-157). These side effects include increased frequency of violent deaths and suicides in the treated group, and it has been suggested that precipitous reduction in plasma lipid levels in middle age may alter membrane physiology in the brain, and thus affect behavior (155). However, no study has suggested that lifelong low plasma cholesterol levels are associated with such risk (158), and this strengthens the argument for early identification of children with $\mathrm{FH}$ and early commencement of lipid-lowering treatment. Furthermore, it is well accepted that atherosclerosis develops in youth, as has been shown recently in a study of postmortem material from young individuals (159). Early identification of children carrying LDL-R gene defects will enable life-style changes, dietary therapy, or, where necessary, drug therapy such as resins to be started, and studies have shown that early commencement of such treatment is associated with better compliance (160). Several studies have shown that measures of total cholesterol or LDL cholesterol alone do not allow unequivocal diagnosis of $\mathrm{FH}$ in $10-15 \%$ of cases, even in the children of a parent with $\mathrm{FH}(161,162)$. We have also recently shown that some children whose lipid levels are initially within 
the normal range for their age and gender show a greater than average rise in lipid levels over time, to a point where it is evident that they have inherited the LDL-R gene mutation (163). Although the frequency of this problem is unknown, there is no doubt that an unequivocal DNA test would be very useful, both to allay fears and to identify children for whom dietary advice and appropriate therapy should be started. When the mutation is known for a patient. DNA tests will give an unequivocal result that can be obtained within 1-2 d.

It has been suggested that a monocyte or lymphocyte assay may be a useful tool for identifying individuals with defective LDL-R function, and there are several reports of such methods (164-166). However, there are considerable technical difficulties with these approaches that prevent their application for routine screening at the present time. In particular, as with all other tests used for diagnosis of $\mathrm{FH}$, there is still overlap between the values obtained for some "normal" individuals and patients with a defect in the receptor, whereas a genetic approach to identify LDL-R defects gives an unequivocal result. At least 12 RFLP of the human LDL-R gene have now been reported $(167,168)$, and the usefulness of such polymorphisms depends on the relative frequency of the alleles and the degree of linkage disequilibrium between the alleles of the different polymorphisms. Using Southern blotting methods and the enzymes Ncol, ApaLI, PuvII, and Stul (169), over $80 \%$ of patients with FH in London are heterozygous for at least one of the RFLP, showing an overall heterozygosity index of 0.7 with a combination of $A$ vall and $N c o l$ being the most useful pair (polymorphism information content 0.61 ). However, the $A p a$ LI and $P v u I I$ variable sites are located in the $5-\mathrm{kb}$ long intron 15 , and so far it has not proved possible to amplify this intron using primers for exon 15 and 16 (unpublished observation). Recently, we have repeated this study for six RFLP detectable by PCR methods using the enzymes SfaNI, TaqI, Stul, HincII, AvaII, and Ncol. For these RFLP, the combination of HincII and Ncol gives the highest pairwise polymorphism information content value of 0.68 , and with the addition of the SfaNI RFLP, $85 \%$ of patients in the sample were heterozygous for at least one polymorphism (170). Recently, variable copy dinucleotide repeat polymorphisms have been reported in the LDL-R gene, which have been detected using an $8 \%$ denaturing polyacrylamide gel (171) or by the SSCP method (10). Although technically more difficult than the PCR methods, these polymorphisms should also be useful for family studies.

With the availability of many RFLP of the LDL-R gene, the main factors determining the success of diagnosis by a family cosegregation approach are uncertainty in the diagnosis caused by individual differences in genetic background or environmental factors, unavailability (due to premature death) of affected relatives to determine phase, and the confounding problem of nonpaternity. In situations of doubt, paternity can be confirmed using genetic tests (172), and a cosegregation study of families of patients with $\mathrm{FH}$ from Munich has recently shown that diagnosis was possible in all cases where samples from four or more relatives were available (173), although this depends on the pedigree structure. The usefulness of such DNA diagnosis has been confirmed by in a recent study from Finland in which relatives of patients with a known mutation in the LDL-R gene were investigated (174). Based on unequivocal DNA diagnosis, $15 \%$ of the relatives were misclassified using only adult lipid data to determine hypercholesterolemia (lipid levels above the 95th percentile). This misclassification was reduced using age- and gender-specific lipid values, but $5 \%$ of relatives were still incorrectly classified as "FH" or "normal" by lipid values alone. In the next few years, it is increasingly likely that the problems of diagnosis by family studies will be avoided by the identification of specific mutations in the LDL-R gene. Until these become routine, unequivocal identification of carriers and noncarriers in the relatives of $\mathrm{FH}$ patients may be aided by cosegregation studies using RFLP $(175,176)$.

Differences in symptoms. In different $\mathrm{FH}$ patients, there is a great deal of variation in the levels of untreated plasma lipids (177) and in the age of onset of coronary artery disease (178). In a recent publication from the UK FH register, strong evidence was obtained for differences in risk of coronary artery disease in different patients, with some individuals developing disease at a very early age, whereas those who had survived past 50 y had a standardized mortality ratio that was only slightly higher than in the general population (179). It has also been shown that the age of onset of coronary artery disease aggregates in families (180), and although it is possible that this may be caused by the presence of environmental or other genetics factors such as genes for higher levels of $L p(a)(181,182)$, it cannot be ruled out that different mutations in the LDL-R gene may be the cause. A recent report from South Africa suggested that the $\mathrm{Val}_{408}-\mathrm{Met}$ mutation is associated with more severe clinical symptoms than the other common mutations in this population, the $A_{s p} p_{206}-G l u$ and the $\mathrm{Asp}_{154}$-Asn mutations (183). If such an association could be established for other mutations, more active therapeutic strategies could be recommended to patients and their relatives who had inherited a mutation associated with a greater risk.

Differences in response to diet or drugs. Several studies have reported that there is a great variation in the fall in total and LDL cholesterol levels when patients with heterozygous $\mathrm{FH}$ are treated with drugs such as resins or hydroxymethylglutarate-CoA reductase inhibitors $(133,184)$. One possibility is that these differences are caused by genetic variation at other loci, and several genes have been shown to be related to baseline lipid levels or response to therapy in patients with FH (185-187). However, given the genetic heterogeneity of the patients recruited for these studies, one can postulate that the variation may be caused by the presence of different mutations in the LDL receptor gene in different patients. This has not been studied in FH patients with well-characterized mutations in the LDL receptor gene, so it is not known whether different mutations in the receptor gene are responsible for any of the observed variation in drug response. The main mechanism of reducing LDL cholesterol with hydroxymethylglutarate-CoA reductase inhibitors is because of a reduced residence time of the LDL cholesterol caused by up-regulation of the normal LDL receptor. The observed variability in response in different patients could thus be mediated through the presence of a partially functioning mutant that augments the novel receptor or a partially inhibiting mutant receptor that interferes with the function of the normal protein. Alternatively, the variability could be caused by a differently functioning normal receptor in different patients (188-191). Recently, a small study has presented evidence to support the suggestion that there may be mutation-specific differences in response (192), and if such differences could be confirmed it would obviously be useful in patient management.

\section{SUMMARY}

Techniques for molecular biology are extremely powerful and have allowed the precise molecular defect to be identified in a number of pediatric patients with disorders of plasma TG and cholesterol metabolism. In very few situations to date has this information been useful to the pediatrician in decisions about the management of the child, but for disorders such as FH or type I hyperlipidemia caused by LPL deficiency, this may be possible in the future if different mutations are found to be associated with better response to a particular therapy or are associated with a different risk for developing disease in later life. For rare disorders that show a recessive pattern of inheritance, the identification of relatives who are carriers is not of great benefit, because the possibility of these marrying another carrier is too low to be of major concern. However, for "codominant" disorders, where carriers have a greater risk of developing clinical symptoms in adulthood, screening relatives to identify carriers will be of major benefit; this applies mainly to the disorders of FH, FDB, and LPL deficiency. For each of these, carriers may 
represent one of 500 in the general population and random or opportunistic screening would be feasible, but a case-finding strategy is likely to be most appropriate to identify individuals who have a specific major-genetic predisposition to hyperlipidemia and thus coronary artery disease. However, before such screening can be started, much more information will be required about the relationship between a specific mutation and the resulting plasma lipid levels that occur in a range of environmental situations, such as different diets, smoking, or drug therapy, as well as the possibility of interaction between the mutation and other ameliorating or exacerbating genetic factors. Only then can appropriate advice be given to an individual about the subsequent long-term risk of developing coronary artery disease. Once such information is available, there will still be ethical dilemmas, and the application of such diagnostic techniques to the relatives of children will require a sensitive collaborative approach from molecular biologists, molecular geneticists, and particularly from pediatricians.

Acknowledgment. The authors thank Gina Deeley for help in preparing the manuscript.

\section{REFERENCES}

1. Lusis AJ 1988 Genetic factors affecting blood lipoproteins: the candidate gene approach. J Lipid Res 29:397-429

2. Humphries SE 1988 DNA polymorphisms of the apolipoprotein genes: their use in the investigation of the genetic component of hyperlipidaemia and atherosclerosis. Atherosclerosis 72:89-108

3. Zannis VI, Kardassis D. Cardot P. Hadzopoulou-Cladaras, Zanni EE Cladaras C 1992 Molecular biology of the human apolipoprotein genes: gene regulation and structure/function relationship. Curr Opin Lipidol 3:96-113

4. Erlich HA 1989 PCR Technology: Principles and Application for DNA Amplification. MacMillan Publishers Ltd. New York

5. Montandon AJ, Green PM. Giannelli F, Bentley DR 1989 Direct detection of point mutations by mismatch analysis: application to haemophilia B. Nucleic Acids Res 17:3347-3358

6. Dunning AM, Houlston R. Frostegard J, Revill J, Nilsson J, Hamsten A Talmud P, Humphries S 1990 Genetic evidence that the putative receptor binding domain of apolipoprotein $B$ (residues 3130 to 3630 ) is not the only region of the protein involved in interaction with the low density lipoprotein receptor. Biochem Biophys Acta 1096:231-237

7. Cotton RG 1989 Detection of single base changes in nucleic acids. Biochem J 263:1-10

8. Myers RM, Fischer SG, Lerman LS, Maniatis T 1985 Nearly all single base substitutions in DNA fragments joined to a GC-clamp can be detected by denaturing gradient gel electrophoresis. Nucleic Acids Res 13:3131-3145

9. Top B, Uitterlindern AG, van der Zee A, Kastelein JJP, Gevers Leuven JA. Havekes LM, Frants RR 1992 Absence of mutations in the promoter region of the low density lipoprotein receptor gene in a large number of familial hypercholesterolaemia patients as revealed by denaturing gradient gel electrophoresis. Hum Genet 89:561-565

10. Orita M, Sekiya T, Hayashi K 1990 DNA sequence polymorphisms in Alu repeats. Genomics 8:271-278

11. Michaud J, Brody LC, Steel G, Fontaine G. Martin LS, Valle D, Mitchell G 1992 Strand-separating conformational polymorphism analysis: efficacy of detection of point mutations in the human ornithine delta-amino transferase gene. Genomics 13:389-394

12. Mailly F, Muller D, Lloyd JK, Durrington PA, Mackness MI, Lithell H, McCarthy S, Betteridge SE, Humphries SE, Talmud PJ 1993 Identification of mutations at the lipoprotein lipase gene locus in subjects with type I hyperlipoproteinemia. Atherosclerosis 98:118

13. Gudnasson V, Mak Y-T, Betteridge J. McCarthy SN. Humphries S 1993 Use of the single strand conformational polymorphism method to detect recurrent and novel mutations in the low density lipoprotein receptor gene in patients with familial hypercholesterolaemia: detection of a novel mutation Asp $_{200}$-Gly. Clin Invest 71:331-337

14. Innis MA, Myambo KB, Gelfand DH, Brow MAD 1988 DNA sequencing with Thermus aquaticus DNA polymerase and direct sequencing of polymerase chain reaction-amplified DNA. Proc Natl Acad Sci USA 85:94369440

15. Chehab FF, Kan YW 1990 Detection of sickle cell anaemia mutation by colour DNA amplification. Lancet 335:15-17

16. Urdea MS, Warner BD, Running JA, Stempien M, Clyne J, Horn T 1988 A comparison of nonradioactive assay methods using fluorescent chemiluminescent and enzyme labeled synthetic oligodeoxyribonucleotide probes. Nucleic Acids Res 16:4937-4957

17. Chang JC, Kan YW 1982 A sensitive new prenatal test for sickle-cell anemia N Eng J Med 307:30-36

18. Newton CR, Graham A. Heptinstall LE, Powell SJ. Summers C. Kalsheker N, Smith JC, Markham AF 1989 Analysis of any point mutation in DNA. The Amplification Refractory System (ARMS). Nucleic Acids Res 17:2503-
2516

19. Old JM, Varawalla NY. Weatherall DJ 1990 Rapid detection and prenatal diagnosis of $\beta$-thalassaemia: studies in Indian and Cypriot populations in the UK. Lancet 2:834-837

20. Snowden C, Houlston RS. Arif MH, Laker MF, Humphries SE. Alberti KGMM 1991 Disparity between apolipoprotein E phenotypes and genotypes (as determined by polymerase chain reaction and oligonucleotide probes) in patients with non-insulin dependent diabetes mellitus. Clin Chim Acta 196:49-58

21. Gille C. Grade K, Coutelle C 1991 A pooling strategy for heterozygote screening of the $J F 508$ cystic fibrosis mutation. Hum Genet 86:289-291

22. Jackson RL 1983 Lipoprotein lipase and hepatic lipase. In: Boyer PD (ed) The Enzymes, Vol 16. Academic Press, New York, pp 141-181

23. Brunzell JD 1989 Familial lipoprotein lipase deficiency and other causes of the chylomicronemia syndrome. In: Scriver CR. Beaudet AL. Sly WS, Valle D (eds) The Metabolic Basis of Inherited Disease. McGraw-Hill, New York pp $1165-1180$

24. Winkler FK, D'Arcy A, Hunziker W 1990 Structure of human pancreatic lipase. Nature 343:77i-774

25. Faustinella F. Chang A. Van Biervliet JP, Rosseneu M. Vinaimont N. Smith LC. Chen S-H, Chan L 1991 Catalytic triad residue mutation (Asp ${ }^{156} \rightarrow$ Gly) causing familial lipoprotein lipase deficiency: co-inheritance with a nonsense mutation (Ser ${ }^{47} \rightarrow$ Ter) in a Turkish family. J Biol Chem 266:14418-14424

26. Faustinella F. Smith LC. Semenkovich CF. Chan L 1991 Structural and functional roles of highly conserved serines in human lipoprotein lipase: evidence that serine 132 is essential for enzyme catalysis. J Biol Chem 266:9481-9485

27. Wang C-S, Hartsuck J, McConathy WJ 1992 Structure and functional properties of lipoprotein lipase. Biochem Biophys Acta 1123:1-17

28. Yang C-Y, Gu Z-W, Yang H-X. Rohde MF, Gotto Jr AM. Pownall HJ 1989 Structure of bovine milk lipoprotein lipase. J Biol Chem 264:16822-16827

29. Enerbäck S, Semb H. Bengtsson-Olivecrona G. Carlsson P. Hermansson ML, Olivecrona T, Bjursell G 1987 Molecular cloning and sequence analysis of cDNA encoding lipoprotein lipase of guinea pig. Gene 58:1-12

30. Sparkes RS, Zollman S. Klisak I, Kirchgessner TG, Komaromy MC. Mohandas T. Schotz MC. Lusis AJ 1987 Human genes involved in lipolysis of plasma lipoproteins: mapping of loci for lipoprotein lipase to $8 \mathrm{p} 22$ and hepatic lipase to $15 \mathrm{q} 21$. Genomics 1:138-144

31. Wion KL, Kirchgessner TG, Lusis AJ, Schotz MC. Lawn RM 1987 Human lipoprotein lipase complementary DNA sequence. Science 235:1638-1641

32. Kirchgessner TG, Svenson KL. Lusis AJ. Schotz MC 1987 The sequence of cDNA encoding lipoprotein lipase. J Biol Chem 262:8463-8466

33. Deeb SS, Peng R 1988 Structure of the human lipoprotein lipase gene. Biochemistry 28:4131-4135

34. Kirchgessner TG, Chuat J-C. Heinzmann C, Etienne J, Guilihot S. Svenson K. Ameis D, Pilon C. d'Auroil L. Andalibi A. Schotz MC. Galibert F, Lusis AJ 1989 Organization of the lipoprotein lipase gene and evolution of the lipase gene family. Proc Natl Acad Sci USA 86:9647-9651

35. Fisher L. Fitzgerald GA. Lawn RM 1987 Two polymorphisms in the human lipoprotein lipase gene. Nucleic Acids Res 15:7657

36. Heizmann C. Ladias J, Antonarakis S, Kirchgessner T. Schotz M. Lusis AJ 1987 RFLP for the human lipoprotein lipase (LPL) gene: HindIII. Nucleic Acids Res 15:6763

37. Hata A. Robertson M. Emi M. Lalouel J-M 1990 Direct detection and automated sequencing of individual alleles after electrophoretic strand separation; identification of a common nonsense mutation in exon 9 of the human lipoprotein lipase gene. Nucleic Acids Res 18:5407-5411

38. Kobayashi J, Nishida T, Ameis D. Stahnke G. Schotz MC, Hashimoto H, Fukamachi I. Shirai K. Saito Y. Yoshida S 1992 A heterozygous mutation (the codon for $\operatorname{Ser}^{447}$ to a stop codon) in lipoprotein lipase contributes to a defect in lipid interface recognition in a case with type 1 hyperlipidemia. Biochem Biophys Res Commun 182:70-77

39. Peacock R. Hamsten A, Nilsson-Ehle P. Humphries S 1992 Associations between lipoprotein lipase gene polymorphisms and plasma correlations of lipids. lipoproteins and lipase activities in young myocardial infarction survivors and age-matched healthy individuals from Sweden. Atherosclerosis $97: 171-185$

40. Beg OU. Meng MS, Skarlatos SI, Previato L. Brunzell JD. Bryan Brewer Jr H, Fojo SS 1990 Lipoprotein lipase $e_{\text {Bethesda: }}$ a single amino acid substitution (Ala-176 to Thr) leads to abnormal heparin binding and loss of enzyme activity. Proc Natl Acad Sci USA 87:3474-3478

41. Ameis D, Kobayashi J. Davis RC. Ben-Zeev O, Malloy MJ. Kane JP, Lee G, Wong H. Havel RJ. Schotz MC 1991 Familial chylomicronemia (type I hyperlipoproteinemia) due to a single missense mutation in the lipoprotein lipase gene. J Clin Invest 97:1165-1170

42. Oka-lshimura K, Semenkovich CF. Faustinella F, Goldberg IJ, Shachter N, Smith LC, Coleman T, Hide WA. Brown V. Oka K. Chan L 1992 A missense (Asp ${ }^{250}$-Asn) mutation in the lipoprotein lipase gene in two unrelated families with familial lipoprotein lipase deficiency. J Lipid Res 33:745-754

43. Emi M, Hata A, Robertson M, Iverius P-H, Hegele R, Lalouel J-M 1990 Lipoprotein lipase deficiency resulting from a nonsense mutation in exon 3 of the lipoprotein lipase gene. Am J Hum Genet 47:107-111

44. Henderson HE, Devlin R, Peterson J. Brunzell JD, Hayden MR 1990 Frameshift mutation in exon 3 of the lipoprotein lipase gene causes a 
premature stop codon and lipoprotein lipase deficiency. Mol Biol Med 7:511-517

45. Ma Y. Henderson HE, Murthy MRV, Roederer G, Monsalve VM, Clarke IA. Normand T. Julien P, Gagné C, Lambert M. Davignon J, Lupien PJ. Brunzell J. Hayden MR 1991 A mutation of the human lipoprotein lipase gene is the most common cause of familial chylomicronemia in French Canadians. N Engl J Med 324:176l-1766

46. Monsalve VM, Henderson H, Roederer G, Julien P. Deeb S. Kasterlein JJP. Peritz I. Devlin R. Brunin T. Murthy MRV. Gagné C. Davignon J, Lupien JP. Brunzell JD. Hayden MR 1990 A missense mutation at codon 188 of the human lipoprotein lipase gene is a frequent cause of lipoprotein lipase deficiency in persons of different ancestries. J Clin Invest 86:728-734

47. Lalouel J-M. Wilson DE. Iverius P-H 1992 Lipoprotein lipase and hepatic triglyceride lipase: molecular and genetic aspects. Curr Opin Lipidol 3:8695

48. Goldstein JL, Hazzard WR. Schrott HG. Bierman GL, Motulsky AG 1973 Hyperlipidemia in coronary heart disease II. Genetic analysis of lipid levels in 176 families and delineation of a new inherited disorder combined hyperlipidemia. J Clin Invest 52:1544-1568

49. Nikilla EA. Aro A 1973 Family study of lipids and lipoproteins in coronary heart disease. Lancet 1:954-958

50. Brunzell JD. Schrott HG. Motulsky AG. Bierman EL 1976 Myocardial infarction in the familial forms of hypertriglyceridemia. Metabolism 25:313-320

51. Sniderman A. Vu H, Cianflone K 1991 Effect of moderate hypertriglyceridemia on the relation of plasma total and LDL apo B levels. Atherosclerosis 89:109-116

52. Hayden MR, Kirk H Clark C Frohlich J, Rabkin S. McLeod R, Hewitt J 1987 DNA polymorphisms in and around the apo-Al-CIIl genes and genetic hyperlipidemias. Am J Hum Genet 40:421-430

53. Wojciechowski AP. Farrall M, Cullen P. Wilson TME. Bayliss JD. Farren B. Griffin BA. Caslake MJ, Packard CJ, Shepherd J, Thakken R. Scott J 1991 Familial combined hyperlipidaemia linked to the apolipoprotein AI-CIIIAIV gene cluster on chromosome 11 q23-q24. Nature 349:16!-164

54. Wilson DE. Emi M, Iverius P-H, Hata A, Wu LL. Hillas E, Williams RR. Lalouel JM 1990 Phenotypic expression of heterozygous lipoprotein lipase deficiency in the extended pedigree of a proband homozygous for a missense mutation. J Clin Invest 86:735-750

55. Babirak SP, Iverius P-H. Fujimoto WY. Brunzell JD 1989 Detection and characterization of the heterozygote state for lipoprotein lipase deficiency. Arteriosclerosis 9:326-334

56. Babirak SP, Brown BG. Brunzell JD 1992 Familial combined hyperlipidemia and abnormal lipoprotein tipase. Arterioscler Thromb 12:1176-1183

57. Williams KJ, Petrie KA. Brocia RW. Swenson TL 1991 Lipoprotein lipase modulates net secretory output of apolipoprotein B in vitro. J Clin Invest 88:1300-1306

58. Beisiegel U. Weber W. Bengtsson-Olivecrona G 1991 Lipoprotein lipase enhances the binding of chylomicrons to low density lipoprotein receptorrelated protein. Proc Natl Acad Sci USA 88:8342-8346

59. Dolphin PJ 1992 Lipolytic enzymes and the role of apolipoproteins in the regulation of their activity. In: Rosseneu $M$ (ed) Structure and Function of Apolipoproteins. CRC Press Inc, Boca Raton, FL. pp 295-362

60. Wei C.F. Tsao Y-K. Robberson DL, Gotto Jr AM. Brown K. Chan L 1985 The structure of the human apolipoprotein C-II gene. Electron microscopic analysis of RNA:DNA hybrids. complete nucleotide sequence, and identification of $5^{\prime}$ homologous sequences among apolipoprotein genes. $\mathrm{J}$ Biol Chem 260:15211-15221

61. Myklebost O. Rogne S 1988 A physical map of the apolipoprotein gene cluster on human chromosome 19. Hum Genet 78:244-247

62. Li W-H. Tanimura M. Luo C-C. Datta S. Chan L 1988 The apolipoprotein multigene family: biosynthesis, structure, structure-function relationships. and evolution. J Lipid Res 29:245-271

63. Holtfreter C. Stoffel W 1988 Expression of normal and mutagenized apolipoprotein CII in prokaryotic cells. Biol Chem Hoppe Seyler 369:1045-1054

64. Santamarina-Fojo S 1992 Genetic dyslipoproteinemias: role of lipoprotein lipase and apolipoprotein C-II. Curr Opin Lipid 3:186-195

65. Baggio G, Manzato E. Gabelli C. Fellin R. Martini S. Baldo Enzi G, Verlato F, Biaocchi MR, Sprecher DL, Kashyap ML. Brewer Jr HB. Crepaldi G 1986 Apolipoprotein C-II deficiency syndrome. J Clin Invest 77:520-527

66. Cox DW, Wills DE, Quan F, Ray PN 1988 A deletion of one nucleotide results in functional deficiency of apolipoprotein $\mathrm{Cll}$ (Apo $\mathrm{CII}_{\text {Toronto }}$ ). J Med Genet 25:649-652

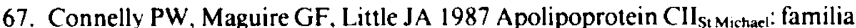
apolipoprotein CII deficiency associated with premature vascular disease. Clin Invest 80:1597-1606

68. Fojo SS, Beisiegel U, Beil U, Higuchi K, Bojanovski M, Gregg RE. Greten $\mathrm{H}$. Brewer Jr HB 1988 Donor splice site mutation in the apolipoprotein (apo) CII gene (apo $\mathrm{CII}_{\text {Hamburg }}$ ) of a patient with apo CII deficiency. $\mathrm{J}$ Clin Invest 82:1489-1494

69. Fojo SS, Stalenhof AFH, Marr K, Gregg RE, Ross RS, Brewer Jr HB 1988 A deletion mutation in the apo C-II gene (apo $\mathrm{CII}_{\text {Nymegen }}$ ) of a patient with a deficiency of apolipoprotein C.II. J Biol Chem 263:17913-17916

70. Fojo SS, Lohse P. Parrott C, Baggio G, Gabelli C. Thomas F, Hoffman J, Brewer Jr HB 1989 A nonsense mutation in the apolipoprotein C-II gene in a patient with apolipoprotein C-Il deficiency. J Clin Invest 84:12151219

71. Crecchio C, Capurso A, Pepe G, Identification of the mutation responsible for a case of plasmatic apolipoprotein C-II deficiency (apo $\mathrm{CII}_{\mathrm{Barl}}$ ). Biochem Biophys Res Commun 168:1118-1127

72. Fojo SS de Gennes JL. Chapman J, Parrott C. Lohse P. Kwan SS. Truffert J. Brewer Jr HB 1989 An initiation codon mutation in the apo C.II gene (apo C-II Paris) of a patient with a deficiency of apolipoprotein C-II. J Biol Chem 264:20839-20842

73. Xiong W. Li W-H. Posner I, Yamamura T. Yamamoto A. Gotto Jr AM. Chan L. 1991 No severe bottleneck during human evolution: evidence from two apolipoprotein CII deficiency alleles. Am J Hum Genet 48:383-389

74. Hegele RA, Breckenridge WC, Cox DW, Maguire GF, Little JA. Connelly PW 199! Interaction between variant apolipoproteins C-II and $E$ that affects plasma lipoprotein concentrations. Arterioscler Thromb 11:13031309

75. Kane JP. Havel RJ 1989 Disorders of the biogenesis and secretion of lipoproteins containing the B apolipoproteins. In: Scriver CR. Beaudet AL. Sly WS. Valle D (eds) The Metabolic Basis of Inherited Disease. McGraw-Hill, New York. pp 1139-1164

76. Knott TJ. Pease RJ. Pwell LM, Wallis SC, Rall SC, Innerarity TL, Blackhart B. Taylor WH, Milner R, Johnson D, Filler M, Lusis AJ, McCarthy BM Levy-Wilson B. Scott J 1989 Complete protein sequence and identification of functional domains of human apolipoprotein B. Nature 323:734-738

77. Pease RJ. Milne RW, Jessup WK, Law A. Provost P. Fruchart J-C. Dean RT, Marcel YL, Scott J 1990 Use of bacterial expression cloning to localize the epitopes for a series of monoclonal antibodies against apolipoprotein B 100 . J Biol Chem 265:553-568

78. Knott TJ, Ball SCJF, Innerarity TL. Jacobson SF, Urdea MS, Levy-Wilson B. Powell LM. Pease RJ. Eddy R. Nakai H. Byers M. Priestly LM. Robertson E. Rall LB. Betsholtz C. Shows TB, Mahley RW. Scott J 1985 Human apolipoprotein B: structure of carboxyl-terminal domains sites of genes expression and chromosome localization. Science 230:37-43

79. Chen SH. Habib G, Yang CY 1987 Apolipoprotein B-48 is the product of a messenger RNA with an organ specific-in-frame stop codon. Science 238:363-366

80. Powell LM, Wallis SC. Pease RJ. Edwards YH. Knott TJ, Scott J 1987 A novel form of tissue specific RNA processing produces apolipoprotein B48 in intestine. Cell 50:831-840

81. Muller DPR. Lloyd JK. Bird AC 1977 Long-term management of abetalipoproteinaemia. Possible role for vitamin E. Arch Dis Child 52:209-214

82. Lackner KJ. Monge JC. Gregg RE. Hoeg JM. Triche TJ. Law SW. Brewer Jr HB 1986 Analysis of the apolipoprotein B gene and messenger ribonucleic acid in abetalipoproteinemia. J Clin Invest 708:1701-1712

83. Bouma ME. Beucler I. Pessah M. Heinzmann C. Lusis AJ, Naim HY. Ducastelle T. Leluyer B. Schmitz J, Infante R. Aggerbeck LP 1990 Description of two different patients with abetalipoproteinemia: synthesis of a normal-sized apolipoprotein B-48 in intestinal organ culture. J Lipid Res $31: 1-15$

84. Dullaart RPF, Speelberg B, Schuurman K-J, Milne RW, Havekes LM. Marcel YL. Geuze HJ. Hulshof MM, Erkelens W 1986 Epitopes of apolipoprotein $\mathrm{B}-100$ and $\mathrm{B}-48$ in both liver and intestine. Expression and evidence for local synthesis in recessive abetalipoproteinemia. J Clin Invest 78:13971404

85. Talmud PJ, Lloyd JK. Muller DPR. Collins DR, Scott J. Humphries S 1988 Genetic evidence from two families that the apolipoprotein $B$ gene is not involved in abetalipoproteinemia. J Clin Invest 82:1803-1806

86. Huang L-S, Jănne PA. Ode Graaf J. Cooper M, Decklebaum RJ. Kayden H. Breslow JL 1990 Exclusion of linkage between the human apolipoprotein $B$ gene and abetalipoproteinemia. Am J Hum Genet 46:1141-1148

87. Leppert M, Breslow JL. Wu L. Hasstedt S, O'Connell P, Lathrop M. Williams RR, White R, Lalouel J-M 1988 Inference of a molecular defect of apolipoprotein $\mathrm{B}$ in hypobetalipoproteinemia by linkage analysis in a large kindred. J Clin Invest 8266:847-851

88. Wagner RD, Krul ES. Tang J, Parhofer KG, Garlock K. Talmud P. Schonfeld G 1991 Apo B 54.8, a truncated apolipoprotein found primarily in VLDL is associated with a nonsense mutation in the apo B gene and hypobetalipoproteinemia. J Lipid Res 32:1001-1011

89. Huang L-S, Ripps ME, Korman SH. Deckelbaum RJ. Breslow JL 1989 Hypobetalipoproteinemia due to an apolipoprotein $B$ gene exon 21 deletion derived by Alu-Alu recombination. J Biol Chem 264:1 1 394-11400

90. Collins DR, Knott TJ, Pease RJ, Powell LM. Wallis SC, Robertson S, Pullinger CR, Milne RW, Marcel YL, Humphries SE, Talmud PJ, Lloyd JK. Miller NE, Muller D, Scott J 1988 Truncated variants of apolipoprotein B cause hypobetalipoproteinemia. Nucleic Acids Res 16:8361-8375

91. Young SG. Hubl ST. Smith RS. Snyder SM. Terdiman JF 1990 Familia hypobetalipoproteinemia caused by a mutation in the apolipoprotein $B$ gene that results in a truncated species of apolipoprotein B (B-31). A unique mutation that helps to define the portion of the apolipoprotein $B$ molecule required for the formation of buoyant, triglyceride-rich lipoproteins. J Clin Invest 85:933-942

92. Young SG. Bertics SJ, Artiss LK, Witztum JL 1987 Characterization of an abnormal species of apolipoprotein B, apolipoprotein B-37, associated with familial hypobetalipoproteinemia. J Clin Invest 79:1831-1841

93. Talmud P. King Underwood L. Krul E, Schonfeld G. Humphries S 1989 The molecular basis of truncated forms of apolipoprotein B in a kindred with compound heterozygous hypobetalipoproteinemia. J Lipid Res 30:17731779

94. Young SG, Hubl ST. Chappel DA. Smith RS. Claiborne F, Snyder SM. 
Terdiman JF 1989 Familial hypobetalipoproteinemia associated with a mutant species of apolipoprotein B (B-46). N Engl J Med 32:1604-1610

95. Hardman DA, Pullinger CR, Hamilton RL, Kane JP, Malloy MJ 199! Molecular and metabolic basis for the metabolic disorder in normotriglyceridemic abetalipoproteinemia. J Clin Invest 88:1772-1792

96. Talmud PJ, Converse C, Krul E. Huq L. Mcllwaine GG, Series JJ, Boyd P. Schonfeld G. Dunning A. Humphries SE 1991 A novel truncated apolipoprotein B (apo B55) in a patient with hypobetalipoproteinaemia and autosomal dominant retinitis pigmentosa. Clin Genet 42:62-70

97. Pullinger CR, Hillas E. Hardman DA. Chi Chen G, Naya-Vigne JM, Lalouel J-M, Wiliams RR, Kane JPA 1990 A mutation in the apolipoprotein B gene results in a truncated variant. apo B61. in VLDL and LDL in a kindred with hypobetalipoproteinaemia. Arteriosclerosis 10:771 a(abstr)

98. Welty FK, Hubl ST, Pierotti VR. Young SG 1991 A truncated species of apolipoprotein B (B67) in a kindred with hypobetalipoproteinemia. J Clin Invest 87:1748-1754

99. Linton MF, Pierotti VR, Hubl ST, Young SG 1990 An apo-B gene mutation causing familial hypobetalipoproteinemia analyzed by examining the apoB cDNA amplified from the fibroblast RNA of an affected subject. Clin Res 38:286A(abstr)

100. Gabelli C. Baggio G, Bilato C, Martini S, Previato L, Marcal Y, Corsini A, Crepaldi G 1989 Identification of a new apo B variant associated with hypobetalipoproteinemia. Circulation 80:II-466(abstr)

101. Graham LD, Pullinger CR, Jones TC, Knott TJ, Scott J 1989 Expression and secretion of apolipoprotein (apo)-B constructs by HepG2 cells. Circulation 80:II-1854(abstr)

102. Yao Z, Blackhart BD, Linton MF. Taylor SM, Young SG, McCarthy BJ 1991 Expression of carboxyl-terminally truncated forms of human apolipoprotein B in rat hepatoma cells: evidence that the length of apolipoprotein B has a major effect on the buoyant density of the secreted lipoproteins. J Biol Chem 266:3300-3308

103. Krul ES, Kinoshita M, Talmud P. Humphries SE. Turner S. Goldberg AC, Cook K. Boerwinkle E, Schonfeld G 1989 Two distinct truncated apolipoprotein $B$ species in a kindred with hypobetalipoproteinemia. Arteriosclerosis 9:856-869

104. Parhofer KG. Daugherty A. Kinoshita M. Schonfeld G 1990 Enhanced clearance from plasma of low density lipoproteins containing a truncated apolipoprotein, apo B-89. J Lipid Res 31:2001-2007

105. Forgez P. Rouis H, Guo H-C. Nigon F. Chapman MJ 1988 Primary and secondary receptor-binding domains in human apo B 100. Circulation 78:II-286(abstr)

106. Converse CA, Keegan WA. Huq L, Series J. Caslake M. McLachlan J, Packard CJ, Shepherd J 1990 Further epidemiological studies in lipid metabolism in retinitis pigmentosa. In: Lavail MM, Hollyfield JG. Anderson RE (eds) Inherited and Environmentally Induced Retinal Degeneration. Alan R Liss. New York, pp 39-47

107. Sigurdsson G, Nicoll A, Lewis B 1977 Turnover of apolipoprotein-B in a two subjects with hypobetalipoproteinemia. Metabolism 26:25-31

108. Pullinger CR, North JD, Teng BB, Rifici VA, Ronhild de Brito AE, Scott J 1989 The apolipoprotein B gene is constitutively expressed in HepG2 cells: regulation of secretion by oleic acid. albumin. and insulin, and measurement of the mRNA half-life. J Lipid Res 30:1065-1077

109. Weisgraber KH, Innerarity TL. Newhouse YM. Young SG. Arnold KS Krauss RM, Vega GL 1988 Familial defective apolipoprotein B-100: enhanced binding of monoclonal antibody MB47 to abnormal low density lipoproteins. Proc Natl Acad Sci USA 85:9758-9762

110. Innerarity JL, Mahley RW. Weisgraber KH. Bersot TP. Krauss RM, Vega GL, Grundy SM, Freidl W, Davignon J. McCarthy BJ 1990 Familial defective apolipoprotein B-100: a mutation of apolipoprotein B that causes hypercholesterolemia. J Lipid Res 31:1337-1349

111. Vega GL, Grundy SM 1986 In vivo evidence for reduced binding of low density lipoproteins to receptors as a cause of primary moderate hypercholesterolemia. J Clin Invest 78:1410-1414

112. Soria LF, Ludwig EH, Clarke HR, Vega GL. Grundy SM. McCarthy BJ 1989 Association between a specific apolipoprotein B mutation and familial defective apolipoprotein B-100. Proc Natl Acad Sci USA 86:587-591

113. Innerarity TL, Balestra ME, Arnold KS, Mahley RW, Vega GL, Grundy SM, Young SG 1988 Isolation of defective receptor-binding low density lipoproteins from subjects with familial defective apolipoprotein B-100. Arteriosclerosis 8:551 a(abstr)

114. Katz SL, Ibadah JA, Letizia JY, Thomas MT, Philipps MC 1988 A 'C NMR characterization of lysine residues in apolipoprotein $\mathrm{B}$ and their role in binding to the low density lipoprotein receptor. J Biol Chem 263:1383113838

115. Innerarity TL 1990 Familial hypobetalipoproteinemia and familial defective apolipoprotein B 100: genetic disorders associated with apolipoprotein B. Curr Opin Lipidol 1:104-109

116. Friedl W, Ludwig EH, Balestra ME, Arnold KS, Paulweber B. Sandhofer F, McCarthy BJ, Innerarity TL 1991 Apolipoprotein B gene mutations in Austrian subjects with heart disease and their kindred. Arterioscler Thromb 11:371-378

117. Tybjærg-Hansen A, Gallagher J, Vincent J, Houlston R. Talmud P. Dunning AM, Seed M, Hamsten A. Humphries SE. Myant NB 1990 Familial defective apolipoprotein B-100: detection in the United Kingdom and Scandinavia, and clinical characteristics of ten cases. Atherosclerosis 80:235-242

118. Schuster H, Rauh G, Korman B, Hepp T. Humphries S, Keller C, Wolfram
G. Zollner N 1990 Familial defective apolipoprotein B-100: comparison with familial hypercholesterolemia in 18 cases detected in Munich. Arteriosclerosis 10:577-581

119. Corsini A. Fantappie S. Granata A. Bernini F, Catapano AL. Fumagalli R, Romano L, Romano C 1989 Binding-defective low-density lipoprotein in family with hypercholesterolaemia. Lancet 1:623

120. Hämäläinen T, Palotie A. Aalto-Setälä K, Kontula, K Tikkanen MJ 1990 Absence of familial defective apolipoprotein B-100 in Finnish patients with elevated serum cholesterol. Atherosclerosis 82:177-183

121. Ludwig EH, McCarthy BJ 1990 Haplotype analysis of the human apolipoprotein B mutation associated with familial defective apolipoprotein B100. Am J Hum Genet 47:712-720

122. Rauh GR. Fischer J. Keller C. Wolfram G. Zollner N 1991 Familial defective apolipoprotein B-100: haplotype analysis of the arginine $e_{(3500)}-$ glutamine mutation. Atherosclerosis $88: 219-226$

123. Talmud P. Tybjaerg-Hansen A. Bhatnagar D. Mbewu A. Miller JP. Durrington $\mathrm{P}$, Humphries $\mathrm{S} 199$ I Rapid screening for specific mutations in patients with a clinical diagnosis of familial hypercholesterolaemia. Atherosclerosis 89:137-141

124. Myant NB. Gallagher JJ, Knight BL. McCarthy SN, Frostegard J. Nilsson J. Hamsten A, Talmud PJ. Humphries SE 1991 Clinical signs of familial hypercholesterolaemia in patients with familial defective apolipoprotein B100 and normal low-density lipoprotein receptor function. Atherosclerosis 11:691-703

125. Tybjaerg-Hansen A. Humphries SE 1992 Familial defective apo B100: a single mutation that causes hyperlipidaemia and premature coronary artery disease. Atherosclerosis 96:91-107

126. Corsini A. Mazzotti M. Fumagalli R. Catapano AL. Romano L. Romano C 1991 Poor response to simvastatin in familial defective apo B100. Lancet 1:305

127. Maher VMG. Gallagher JJ. Thompson GR, Myant NB 1991 Response to cholesterol-lowering drugs in familial defective apolipoprotein B-100. Atherosclerosis $91: 73-76$

128. Illingworth DR. Jaker F. Mahley RW, Weisgraber KH 1992 Hypocholesterolaemic effects of lovostatin in familial defective apolipoprotein B-100. Lancet 1:598

129. Goldstein JL. Brown MS 1989 Familial hypercholesterolemia. In: Scriver CR. Beaudet AL, Sly WS, Valle D (eds) The Metabolic Basis of Inherited Disease, 6th Ed. McGraw-Hill Book Co. New York, pp 1215-1250

130. Slack J 1969 Risks of ischaemic heart disease in familial hyperlipoproteinaemic states. Lancet 2:1380-1382

131. Goldstein JL. Hazzard WR. Schrott HG. Bierman EL, Motulsky AG 1973 Hyperlipidemia in Coronary Heart Disease. Part I. Lipid levels in 500 survivors of myocardial infarction. J Clin Invest 52:1533-1543

132. Tyroler HA 1985 Lowering blood cholesterol to prevent heart disease. JAMA 253:2080-2086

133. Illingworth DR, Sexton GJ 1984 Hypocholesterolemic effects of mevinolin in patients with heterozygous familial hypercholesterolemia. J Clin Invest 74:1972-1978

134. Nutrition Committee and Council on Arteriosclerosis 1984 Recommendations for treatment of hyperlipidemia in adults. Circulation 69:1067A$1090 \mathrm{~A}$

135. Kwiterovich Jr PO 1989 Pediatric implications of heterozygous familial hypercholesterolemia: screening and dietary treatment. Atherosclerosis 9(Suppl I): $111-120$

136. Khachadurian AK 1968 Cholestyramine therapy in patients homozygous in familial hypercholesterolemia. J Atherosclerosis Res 8:177-188

137. Keller C 1991 LDL-apheresis: results of long-term treatment and vascular outcome. Atherosclerosis $86: 1-8$

138. Starzl TE, Bilheimer DW, Bahnson HT, Shaw Jr BW, Hardesty RL Griffith BP, Iwatsuki S. Zitelli BJ, Gartner Jr JC. Malatack JJ, Urbach AH 1984 Heart-liver transplantation in a patient with familial hypercholesterolaemia. Lancet 1:1382-1383

139. Tolleshaug H. Hobgood KK. Brown MS, Goldstein JL 1983 The LDL receptor locus in familial hypercholesterolemia: multiple mutations disrupt transport and processing of a membrane receptor. Cell 32:941-951

140. Hobbs HH, Russell DW. Brown MS. Goldstein JL 1990 The LDL receptor locus in familial hypercholesterolaemia: mutational analysis of a membrane protein. Ann Rev Genet 24:133-170

141. Yamamoto T. Davis LG, Brown MS, Schneider WJ. Casey ML. Goldstein JL, Russell DW 1984 The human LDL-receptor: a cysteine-rich protein with multiple Alu sequences in its mRNA. Cell 39:27-38

142. Hobbs HH. Brown MS. Russell DW. Davignon J, Goldstein JL 1987 Deletion in the gene for the low-density-lipoprotein receptor in a majority of French Canadians with familial hypercholesterolemia. N Engl J Med 12:734-737

143. Leitersdorf E, Tobin EJ, Davignon J. Hobbs HH 1990 Common low-density lipoprotein receptor mutations in the French Canadian population. J Clin Invest 85:1014-1023

144. Aalto-Setälä K. Gylling H, Miettinen T, Kontula K 1988 Identification of a deletion in the LDL receptor gene. A Finnish type of mutation. FEBS Lett 234:411-416

145. Top B, Koeleman BPC, Gevers Leuven JA. Havekes LM. Frants RR 1990 Rearrangements in the LDL receptor gene in Dutch familial hypercholesterolaemic patients: presence of a common $4 \mathrm{~kb}$ deletion. Atherosclerosis 83:127-136

146. Leitersdorf E, van der Westhuyzen DR. Coetzee GA, Hobbs HH 1989 Two 
common low density lipoprotein receptor gene mutations cause familial hypercholesterolemia in Afrikaners. J Clin Invest 84:954-96!

147. Meiner V, Landsberger D, Berkman N, Reshef A, Segal P. Seftel HC, van der Westhuyzen DR. Jeenah M, Coetzee GA, Leitersdorf E 1991 A common Lithuanian mutation causing familial hypercholesterolemia in Ashkenazi Jews. Am J Hum Genet 49:443-449

148. Landsberger D. Meiner V, Reshef A. Levy Y, van der Westhuyzen DR. Coetzee GA, Leitersdorf E 1992 A nonsense mutation in the LDL receptor gene leads to familial hypercholesterolemia in the Druze sect. Am J Hum Genet 50:427-433

149. Gudnason V, King-Underwood L, Soutar AK, Sun X-M, Munro A, Humphries SE 1993 Screening for mutations in exon 4 of the low density lipoprotein receptor gene in patients with familial hypercholesterolaemia in the UK. Arterioscler Thromb 13:56-63

150. Webb JC, Sun XM, Patel DD. McCarthy SN. Knight BL. Soutar AK 1992 Characterization of two point mutations in the low density lipoprotein receptor gene of an English patient with homozygous familial hypercholesterolemia. J Lipid Res 33:689-698

151. Horsthemke B. Dunning A. Humphries S 1987 Identification of deletions in the human low density lipoprotein (LDL) receptor gene. J Med Genet 24:144-147

152. Sun X-M, Webb JC, Gudnason V, Humphries S, Seed M. Thompson GR Knight B. Soutar AK 1992 Characterisation of deletions in the low density lipoprotein gene in patients with familial hypercholesterolaemia in the UK. Arterioscler Thromb 3:689-698

153. King-Underwood L. Gudnason V. Humphries S. Seed M. Patel D. Knight B, Soutar A 1991 Identification of the 664 proline to leucine mutation in the low density lipoprotein receptor in four unrelated patients with familial hypercholesterolaemia in the UK. Clin Genet 40:17-28

154. Hobbs HH, Leitersdorf E, Leffert CC. Crver DR, Brown MS, Goldstein JL 1989 Evidence for a dominant gene that suppresses hypercholesterolemia in a family with defective low density lipoprotein receptors. J Clin Invest $84: 656-664$

155. Engelberg H 1992 Low serum cholesterol and suicide. Lancet 1:727-729

156. Lindberg G. Rảstam L. Gullberg B, Eklund GA 1992 Low serum cholesterol concentration and short term mortality from injuries in men and women. Br Med J 305:277-279

157. Epstein FH 1992 Low serum cholesterol, cancer and other noncardiovascular disorders. Atherosclerosis $94: 1-12$

158. Keys A 1980 The seven countries study. Harvard University Press, Cambridge. MA

159. Hixson JE and the Pathobiological Determinants of Atherosclerosis in Youth (PDAY) Research Group 1991 Apolipoprotein E polymorphisms affect atherosclerosis in young males. Arterioscler Thromb !1:1237-1244

160. West RJ. Lloyd JK 1980 Long-term follow-up of children with familial hypercholesterolemia treated with cholestyramine. Lancet 2:873-875

161. Kwiterovich PO. Fredrickson DS, Levy RI 1974 Familial hypercholesterole. mia (one form of familial type Il hyperlipoproteinaemia): a study of its biochemical. genetic and clinical presentation in childhood. J Clin Invest 53:1237-1249

162. Leonard JV. Whitelaw AGL. Wolff OH. Lloyd JK. Slack J 1977 Diagnosing familial hypercholesterolaemia in children by measuring serum cholesterol. Br Med J 1:1566-1568

163. Kessling AM. Seed M. Taylor R, Wynn V, Humphries SE 1990 Rising cholesterol levels in children with familial hypercholesterolaemia. Biomed Pharmacother 40:373-379

164. Cuthbert JL, East CE, Bilheimer DW. Lipsky PE 1986 Detection of familial hypercholesterolemia by assaying functional low-density lipoprotein receptors on lymphocytes. N Engl J Med 314:879-883

165. Benhamamouch S, Kusnierz J.P. Agnani G, Marzin D. Leierf JM. Fruchar JC, Clavey V 1988 Determination of the LDL receptor binding capacity of human lymphocytes by immunocytofluorimetric assay. Biochim Biophys Acta 1002:45-53

166. Schmitz G, Wolf D, Brunning T, Assman G 1987 Detection of LDL-binding sites on human white blood cells by flow cytometry. Clin Chem 33:21952202

167. Leitersdorf E, Chakravarti A, Hobbs HH 1989 Polymorphic DNA haplotypes at the LDL receptor locus. Am J Hum Genet 44:409-421

168. Soutar AK 1991 A polymorphism in exon 2 of the human LDL-R gene (LDLR). Nucleic Acids Res 19:4314

169. Taylor R, Jeenah M, Seed M, Humphries S 1988 Four DNA polymorphisms in the LDL receptor gene: their genetic relationship and use in the study of variation at the LDL receptor locus. J Med Genet 25:653-659

170. Humphries S, King-Underwood L, Gudnason V, Seed M, Delattre S, Clavey V. Fruchart J-L 1993 Six DNA polymorphisms in the low density lipopro- tein-receptor gene: their genetic relationship and an example of their use for identifying affected relatives of patients with familial hypercholestero. laemia. J Med Genet 30:273-279

171. Zuliani G. Hobbs HH 1990 Dinucleotide repeat polymorphism at the $3^{\prime}$ end of the LDL receptor gene. Nucleic Acids Res 18:4300

172. Jeffreys AJ. Brookfield JFY. Semeonoff R 1985 Positive identification of an immigration test case using human DNA fingerprints. Nature 317:818-819

173. Schuster H. Steifenhofer B, Wolfram G. Keller CH. Humphries S, Huher A Zollner N 1992 Four DNA polymorphisms in the LDL-receptor gene and their use in diagnosis of familial hypercholesterolemia. Hum Genet 82: 69-72

174. Koivisto PVI, Koivisto U-M, Miettinen TA, Kontula K 1992 Diagnosis of heterozygous familial hypercholesterolemia. DNA analysis complements clinical examination and analysis of serum lipid levels. Arterioscler Thromb 12:584-592

175. Humphries SE, Taylor R, Jeenah M. Dunning A. Horsthemke B. Seed M Schuster $\mathrm{H}$. Wolfram G 1989 Gene probes in the diagnosis of familial hypercholesterolaemia. Arteriosclerosis 9:59-65

176. Humphries SE. Taylor R, Jeenah M. Dunning A. Horsthemke B. Seed M Schuster H. Wolfram G 1989 Gene probes in the diagnosis of familial hypercholesterolaemia. Arteriosclerosis 9:59-65

177. Nora JJ, Loitscher RM. Spangler RD. Bilheimer DW 1985 I. Familial hypercholesterolaemics with "normal" cholesterol in obligatory heterozy. gotes. Am J Med Genet 22:585-591

178. Hill JS, Hayden MR. Frohlich J, Pritchard H 1991 The incidence of coronary artery disease in heterozygous familial hypercholesterolemia. Arterioscler Thromb 11:290-297

179. Betteridge DJ, Broome K. Durrington PN, Mann JI, Miller JP. Neil HAW Thompson GR. Thorogood M 1991 Risk of fatal coronary heart disease in familial hypercholesterolaemia. Br Med J 303:893-896

180. Heiberg A. Slack J 1977 Familial similarities in the age at coronary death in familial hypercholesterolaemia. Br Med J 294:493-495

181. Seed M. Hoppichler F, Reaveley D, McCarthy S. Thompson GR, Boerwinkle E. Utermann G 1990 Relation of serum lipoprotein(a) concentration and apolipoprotein(a) phenotype to coronary heart disease in patients with familial hypercholesterolemia. N Engl J Med 322:1494-1499

182. Soutar AK, McCarthy SN, Seed M, Knight BL 1991 Relationship between apolipoprotein(a) phenotype, lipoprotein(a) concentration in plasma, and low density lipoprotein receptor function in a large kindred with familial hypercholesterolemia due to the pro664-leu mutation in the LDL receptor gene. J Clin Invest 88:483-492

183. Kotze MJ, Langenhoven E, Kriek JA, Oosthuizen CJJ, Retief AE 1992 DNA screening of hyperlipidemic Afrikaners for familial hypercholesterolemia. J Med Genet 42:43-46

184. Havel RJ, Hunninghake DB, Illingworth DR, Lees RS, Stein EA, Tobert JA Bacon SR, Bolognese JA. Frost PH. Lamkin GE 1987 Lovastatin (mevi nolin) in the treatment of heterozygous familia! hypercholesterolemia. Ann Intern Med 107:609-615

185. Nestruck CA. Bouthiller D. Sing CF. Davignon J 1987 Apolipoprotein E polymorphism and plasma cholesterol response to probucol. Metabolism 36:743-747

186. O.Malley JP, Illingworth DR 1990 The influence of apolipoprotein E phenotype on the response to lovastatin therapy in patients with heterozygous familial hypercholesterolemia. Metabolism 39:150-154

187. Ojala J-P. Helve E. Ehnholm C. Aalto-Setälä K. Kontula KK. Tikkanen MJ 1991 Effect of apolipoprotein $E$ polymorphism and Xbal polymorphism of apolipoprotein $B$ on response to lovastatin treatment in familial and nonfamilial hypercholesterolaemia. J Internal Med 230:397-405

188. Maartmann-Moe K. Magnus P. Goldern W. Berg K 1981 Genetics of the low density lipoprotein receptor: III. Evidence for multiple normal alleles at the low density lipoprotein receptor locus. Clin Genet 20:113-129

189. Pedersen JC. Berg K 1988 Normal DNA polymorphism at the low density lipoprotein receptor (LDLR) locus associated with serum cholesterol levels. Clin Genet 34:306-312

190. Schuster H. Humphries S, Rauh G, Heid C, Keller CH. Wolfram G. Zollner N 1990 Association of DNA-haplotypes in the human LDL-R gene with normal serum cholesterol levels. Clin Genet 38:401-404

191. Humphries S. Coviello DA. Masturzo P. Balesteri R. Orecchini G. Bertolin $S 1991$ Variation in the low density lipoprotein receptor gene is associated with differences in plasma low density lipoprotein cholesterol levels in young and old normal individuals from Italy. Arterioscler Thromb 11:509_ 516

192. Jeenah M. September W, Graadt van Roggen F. de Villiers W. Seftel H Marais D 1993 Influence of specific mutations at the LDL-receptor locus on the response to simvastatin therapy in Afrikaner patients with heterozygous familial hypercholesterolaemia. Atherosclerosis 98:51-58 